The Quest for Price Stability in Central America and the Dominican Republic

\author{
Luis I. Jácome H. and Eric Parrado
}



IMF Working Paper

Monetary and Capital Markets Department

\title{
The Quest for Price Stability in Central America and the Dominican Republic ${ }^{*}$
}

\author{
Prepared by Luis I. Jácome H. and Eric Parrado
}

Authorized for distribution by Carlos Medeiros

March 2007

\begin{abstract}
This Working Paper should not be reported as representing the views of the IMF. The views expressed in this Working Paper are those of the author(s) and do not necessarily represent those of the IMF or IMF policy. Working Papers describe research in progress by the author(s) and are published to elicit comments and to further debate.

This paper addresses the question of why inflation has not yet converged to price stability in Central America and the Dominican Republic and is currently relatively high by Latin American standards. It suggests that despite the institutional strengthening of monetary policy, important flaws remain in most central banks, in particular a lack of a clear policy mandate and little political autonomy, which are adversely affecting the consistency of policy implementation. Empirical analysis reveals that all central banks raise interest rates to curtail inflation but only some of them increase it sufficiently to effectively tackle inflation pressures. It also shows that some central banks care simultaneously about exchange rate stability. The potential policy conflict arising from a dual central bank mandate and the unpredictable policy response is probably undermining markets' confidence in central banks' commitment to price stability, thereby perpetuating an inflation bias.
\end{abstract}

JEL Classification Numbers: E42, E52, E58.

Keywords: Monetary policy, inflation, Central America, monetary policy rules.

Author's e-mail address: ljacome@imf.org, eparrado@bcentral.cl

\footnotetext{
* We are thankful for valuable comments provided by Alain Ize, Fabián Valencia, Jerome Vandenbussche, and staff from the IMF's Western Hemisphere Department. Remaining errors and omissions are the sole responsibility of the authors.
} 
I. Introduction 3

II. The Institutional Framework for Monetary Policy in Central America........................................... 5

A. A Snapshot of Central Banks' Reforms and their Main Flaws ........................................... 5

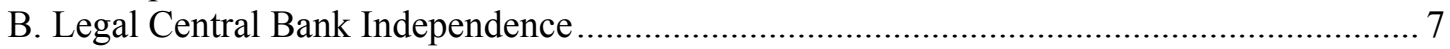

III. Characterizing Monetary Policy: A Preliminary View …......................................................... 11

A. Formulation and Implementation of Monetary Policy in Central America........................ 12

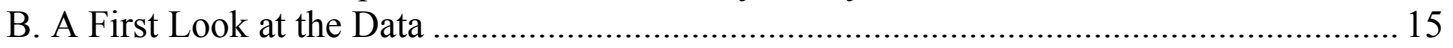

IV. Empirical Regularities Supporting the Characterization of Monetary Policy.............................. 16

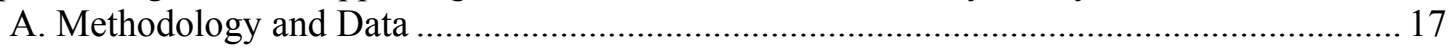

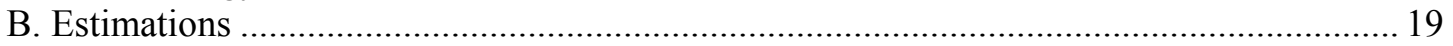

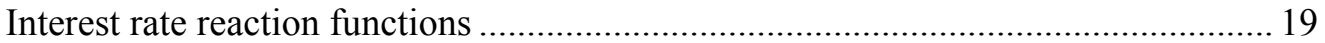

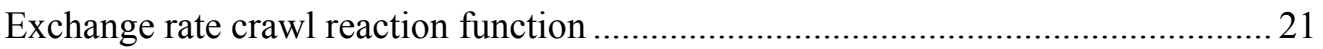

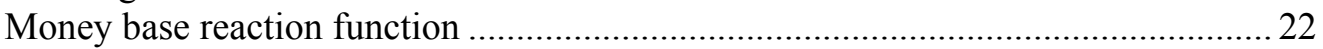

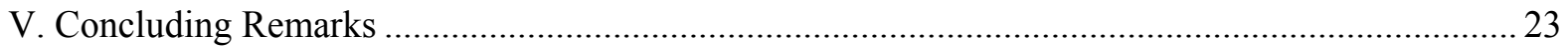

Tables

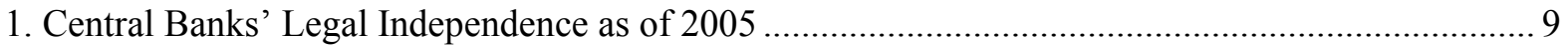

2. Inflation performance in Central America...................................... 10

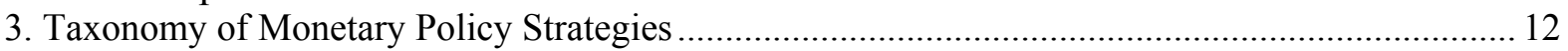

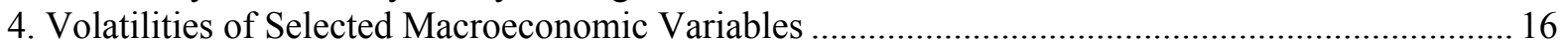

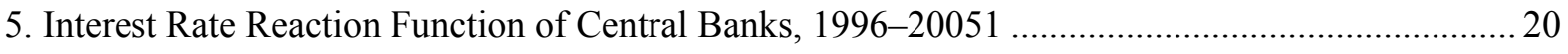

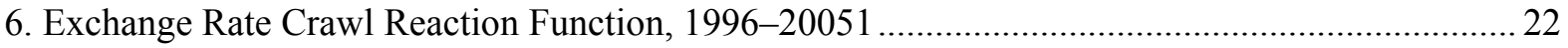

7. Central Banks' Money Reaction Function, 1996-2005 ….......................................................... 23

Figures

1. Inflation in Central America and the Western Hemisphere.......................................................

2. Inflation in Central America, Western Hemisphere, and Industrial Countries......................4

3. Legal Central Banks Independence Before and After the Reform................................... 8

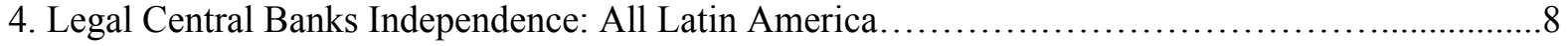

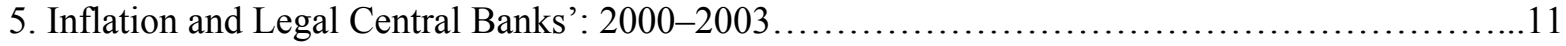

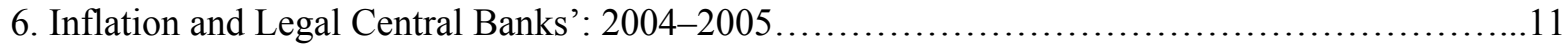

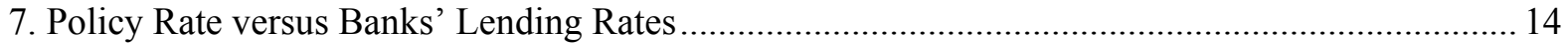

Appendices

I. Central America: Main Provisions of Central Bank Legislation as of 2005 …............................... 26

II. Central America: Main Features of Monetary Policy ................................................................... 29

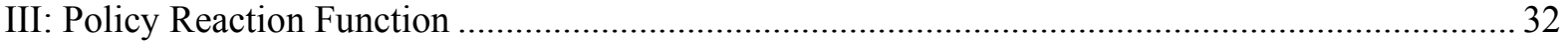

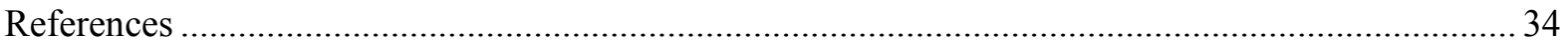




\section{INTRODUCTION}

Compared with the rest of Latin America, Central America and the Dominican Republicfrom now on referred only as Central America - have a history of low inflation. No country, except Nicaragua, fell into the clutches of hyperinflation, and during the late-1990s and early 2000s, inflation dropped into single-digit rates (Figure 1). The downward trend in inflation across Central America has been accompanied by different patterns of monetary policy regimes. In addition to Panama's century-old formal dollarization and the recently adopted dollarization in El Salvador, Costa Rica, Honduras, and Nicaragua have chosen an exchange rate-based policy regime, whereas the Dominican Republic and Guatemala have in place money and inflation targeting regimes, respectively. ${ }^{1}$ On these grounds, the dollarized economies abdicated their right to conduct monetary policy, whereas those using the exchange rate as a nominal anchor maintained at best a little room for maneuver. Only countries with a flexible exchange rate regime have been in a position to preserve an independent conduct of monetary policy_provided the exchange rate is effectively floating.

Nonetheless, price stability in most Central America has been elusive, and moreover, these countries seem to be vulnerable to a rebound in inflation as a result of exogenous shocks. Except for the formally dollarized economies, inflation in the Central American economies never converged to world inflation and rather, in the current decade, it has stalled above that in the historically high inflation countries in Latin America (Figure 2).

This paper explores the monetary reasons underlying inflation's performance in Central America during the recent period. ${ }^{2}$ It addresses the question of why inflation has not yet converged to price stability and is relatively high, both in absolute terms and in comparison with the rest of Latin America. We define price stability as a situation of low and stable inflation, for example, similar to that in the United States-Central America's main trading partner. ${ }^{3}$ Implicitly, the paper stresses the importance of achieving price stability as it favors Central American countries in attaining maximum economic growth. ${ }^{4}$ The analysis includes Costa Rica, Guatemala, Honduras, and Nicaragua plus the Dominican Republic. ${ }^{5}$

\footnotetext{
${ }^{1}$ This characterization is based on the 2005 IMF's Annual Report on Exchange Arrangements and Exchange Restrictions.

2 The paper does not examine cost-push factors stemming from the recent oil shock.

${ }^{3}$ As it is well known, there is no single definition of price stability, and hence, the notion of achieving low and stable inflation has become standard among academics and practitioners to refer to price stability.

${ }^{4}$ The empirical evidence suggests that inflation starts to restrict economic growth even at high single-digit rates of inflation (see Carstens and Jácome, 2005 for a brief tour of this literature).

${ }^{5}$ References to El Salvador and Panama are occasionally made but only for comparative purposes.
} 
Figure 1. Inflation in Central America and the Western Hemisphere

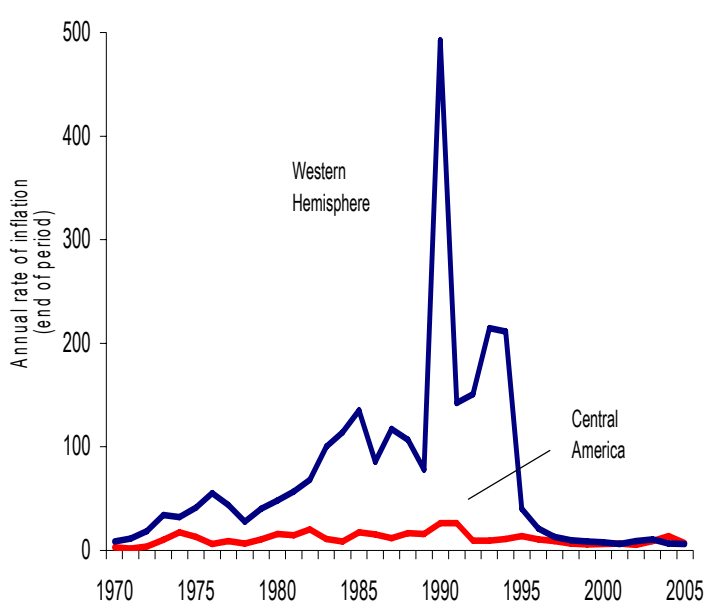

Note: Central America excludes Nicaragua Source: IMF, International Financial Statistics
Figure 2. Inflation in Central America, the Western Hemisphere, and Industrial Countries

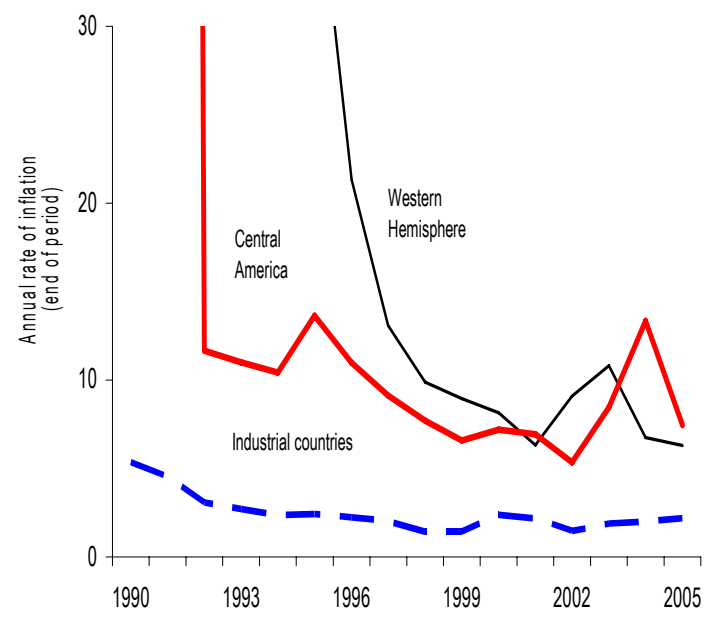

Note: Central America includes Nicaragua Source: IMF, International Financial Statistics

In particular, our paper examines the institutional foundations underpinning the formulation and management of monetary policy and analyses empirically how central banks in Central America react in practice, which is eventually driving market expectations, and hence, inflation. The proposed analysis is relevant for both academic and policy reasons. Despite relatively high inflation in Central America, monetary policy has not been addressed recently in the literature, and hence, this paper makes an attempt to fill this void. The latest studies have rather focused on other macroeconomic policies, structural reforms, regional integration issues, and even on exchange rate policies without paying sufficient attention to monetary policies. ${ }^{6}$ From a policy perspective, it provides "food for thought" to practitioners and policy-makers that seek to boost the effectiveness of monetary policy in Central America with the aim of achieving the elusive objective of price stability.

The rest of the paper is organized as follows: Section II examines the institutional basis underpinning the formulation of monetary policy in Central America. Section III seeks to characterize the implementation of monetary policy in these countries. Section IV explores empirical regularities about the conduct of monetary policy during the period 1996-2005. Section V provides the main conclusions of the analysis. In addition, Appendix I offers a stylized presentation of the legal basis for monetary policy in Central American countries and Appendix II spells out the responses from Central American central banks to a questionnaire regarding their policy objectives, as well as the instruments and operational arrangements underlying the conduct of monetary policy.

\footnotetext{
${ }^{6}$ See the collection of papers on Central America in Rodlauer and Schipke (2005), and Rennhack and Offerdal (2004), in which an analysis of monetary policy is absent.
} 


\section{The Institutional Framework for Monetary Policy in Central America}

During the last 15 years, all countries in Central America strengthened the institutional underpinnings for the formulation and execution of monetary policy. ${ }^{7}$ New central bank legislation was enacted, starting with Nicaragua in 1992 (and 1999) and followed by Costa Rica in 1995, Honduras in 1996 (and 2004), and Guatemala and the Dominican Republic in 2002. The new central bank charters mirrored the pattern of previous reforms adopted in other countries in Latin America. ${ }^{8}$ These legal reforms were aimed at introducing price stability as a central bank policy objective, expanding their political and operational autonomy, and requiring central banks to be accountable and transparent. Despite this institutional strengthening, the reforms did not overcome important institutional flaws, which seem to be adversely affecting the conduct of monetary policy, thereby hampering central banks' credibility and eventually undermining their ability to defeat inflation. We briefly discuss below the major components of central bank reforms in Central America and compare them with those adopted by the rest of Latin America. A stylized presentation of the main features of today's central bank legislation in Central America is found in Appendix I.

\section{A. A Snapshot of Central Banks' Reforms and their Main Flaws}

Following institutional reforms, central banks in Central America no longer behave as development banks and are currently more focused on bringing down inflation. Like in the rest of Latin America, central banks used to mostly focus on fostering economic growthproviding credit to specific sectors under preferential financial conditions - in line with governments' economic policy priorities. Alternatively, the new legal mandate requires them to focus on arresting inflation as a necessary - although not sufficient-condition for economic growth, which reflects the consensus in the profession with respect to the inability of monetary policy to influence real variables. However, in Costa Rica and Honduras, this policy mandate is accompanied by other objectives, such as preserving simultaneously the external value of their currencies. The coexistence of these two objectives has at times become mutually incompatible, in particular when the exchange rate went through periods of appreciation, which central banks sought to avoid despite their anti-inflation effect.

Changes in central banks' policy mandate were not reinforced by strong political autonomy. De jure political autonomy is still weak in most central banks in Central America as central bank governors are appointed and potentially dismissed by the President of the Republiclike it used to be before the monetary reform. In addition, central bank governors' tenure coincide with that of the executive branch and in the Dominican Republic is even shorter (only two years). Hence, central banks' policy formulation remains in theory closely tied to the countries' political business cycle, which restricts the chances of minimizing timeinconsistency problems that result in an "inflation bias." In addition, in countries such as the

\footnotetext{
${ }^{7}$ Even El Salvador reformed its central bank law in 1991, before adopting the dollar as its legal tender in 2001.

${ }^{8}$ See Carstens and Jácome (2005) for an extensive review of the nature and scope of central banks' reform in Latin America.
} 
Dominican Republic and Guatemala, the private sector is still closely involved in the appointment of members of the central bank board, thereby providing another source of potential external influence on the formulation of monetary policy.

Operational independence of central banks is today a common pattern region-wide, although a number of factors undermine such independence. In general, central banks in Central America exhibit instrument independence as they are empowered to freely execute monetary policy without interference from either the government or the private sector. In particular, central banks have the legal authority, to use monetary policy instruments to influence market interest rates, thereby potentially affecting aggregate demand, and hence, inflation. They are also legally restricted - and even prohibited like in Guatemala - to extend credit to finance government spending, except for short-term advances to cope with seasonal liquidity shortages (Honduras and Nicaragua). Furthermore, in Costa Rica, Honduras, and Guatemala, the central bank is a filter to restrain public debt increases, as it is legally required to provide a technical opinion about the appropriateness of new public debt issuance.

However, operational autonomy is undermined in most countries because of central banks' lack of effective financial autonomy or due to a subtle form of fiscal dominance. While the reform of central banks' charter got rid of quasi-fiscal expenditures, they have accumulated over time significant losses stemming inter alia from their involvement in banking crises. More recently, the financial position of central banks has deteriorated due to the decline in inflation - which reduced seigniorage - and the increase in the costs of carrying growing international reserves. Central bank losses, if sufficiently large, may limit either their capacity to mop up excess liquidity or their ability to raise interest rates when conducting open-market-operations. Thus, higher interest payments become a source of monetization that requires subsequent sterilization efforts and generate additional costs - which central banks may seek to avoid in Central America. Thus, persistent large losses are, to some extent, limiting the operating capacity of central banks and eventually curtailing the effectiveness of monetary policy actions. ${ }^{9}$ Against this backdrop, legal provisions to protect the integrity of central banks' capital exist in the Dominican Republic, Guatemala, and Nicaragua, where governments are compelled to make up for central bank losses-if they can not be compensated with statutory reserves. In practice, this legal mandate has not materialized in the Dominican Republic and Nicaragua and only partially in Guatemala, where the government covers central bank's operational losses with a two year lag issuing securities at below-market interest rates.

There are other factors that potentially can undermine central banks' operational autonomy. For example, Guatemala faces a legal restriction on operational autonomy as the Congress has to authorize the issuance of central bank paper for open market operations purposes. In Honduras, the annual government's budget approved by Congress establishes a mandatory transference (not a credit) from the central bank to the Government. Although these transfers have not been significant up to now, this practice represents a violation to the principle of banning central banks' financing government's expenditure. Another distorting practice is

\footnotetext{
${ }^{9}$ In most Central American countries, central bank losses exceed 1 percent of GDP every year.
} 
found in Costa Rica, where the central bank and the government conduct simultaneous auctions and bidders are assigned these securities indistinctively at a given-non-market determined - interest rate. The problem arises because the government and the central bank preferences are not compatible, which may happen because the former is guided by price considerations (a low interest rate to minimize debt service) and the latter by quantity criteria (tighten monetary policy). In practice, government preferences tend to prevail over those of the central bank, resulting on interest rates not compatible with the monetary policy stance.

On the other hand, accountability requirements are a key innovation in central bank legislation in Central America but there is still some room for improvement, including through transparency policies. With the current legal provisions, central banks have become more accountable with respect to the autonomy they enjoy, producing more timely reports about the general stance of monetary policy. This is a major upgrade with respect to the prereform practice of simply preparing and publishing an annual report that covered major economic developments in the previous year. Nonetheless, central banks' accountability might be further strengthened by gradually incorporating current policy analyses and projections into monetary and inflation reports, as many emerging markets are already doing, and by requiring central bank authorities to appear regularly in Congress to explain the policies adopted to achieve their targets. De jure transparency has also improved in most countries as all central banks are required to disclose their financial statements. However, financial statements are generally not compatible with international accounting standards, thereby undermining central banks' transparency.

In sum, while monetary policy in Central America has received an injection of institutional strength from the reform of central banks' legislation, important flaws still remain. These relate to the lack of an unequivocal policy mandate aimed at pursuing price stability as a primary objective, while political independence is still short of what is needed to secure an autonomous formulation of monetary policy over a long-term horizon. The latter also restricts central banks' enhanced de jure operational autonomy because the execution of monetary policy must observe the guidelines laid out by non-independent central bank governing bodies. These institutional weaknesses may be potentially hindering central banks' credibility, which is reflected in a persistent "inflation bias" or in higher interest rates than would otherwise be required to defeat inflation.

\section{B. Legal Central Bank Independence}

As a result of its legal reform, central banks in Central America achieved enhanced institutional strength in all fronts, thereby increasing their autonomy to formulate and execute monetary policy. With the aim of measuring the augmented independence of central banks, we use an index that, in essence, gives credit for legal provisions that grant central banks the institutional capacity to arrest inflation and penalizes their role as government financiers and active participants of the political business cycle.

We borrow from Jácome and Vázquez (2005) the index of legal central bank independence, which is built on the spirit of Cukierman's index (Cukierman, 1992), the best known and most widely accepted metric to assess central banks' legal independence. The index used in 
this paper makes some changes to the four criteria in Cukierman's index, which captures key features of central banks' legal independence, namely: (i) political independence; (ii) policy mandate; (iii) policy formulation; and (iv) central banks' lending provisions. It also adds a fifth criterion that measures accountability and transparency provisions. In general, the index gives credit to central banks that feature enhanced political independence, which implies having a government body whose appointment and removal is not in the hands of the executive exclusively - but, typically, also of the legislative - and its tenure exceed the presidential term. The index also assigns the highest marks to those central banks that primarily pursue the objective of preserving price stability. In addition, the index rewards autonomous central banks in the formulation of monetary policy. The fourth criterion favors central banks that face legal restrictions to lend to the government, that have limited capacities to act as lender of last resort, and that benefits from legal support demanding the government to assure central banks' financial independence. The fifth criterion positively evaluates central banks' accountability and transparency requirements.

By assessing old and new central banks' legislation - and the relevant aspects of the national constitutions - we come to the conclusion that central banks are today significantly more independent than in their pre-reform period (Figure 3). ${ }^{10}$ On a regional perspective, despite the achievements of these institutional reforms, Central American central banks still lag behind most in South America and Mexico, in particular Bolivia, Chile, Colombia, Mexico, and Peru (Figure 4).

Figure 3. Legal Central Banks Independence (Before and after the reform)

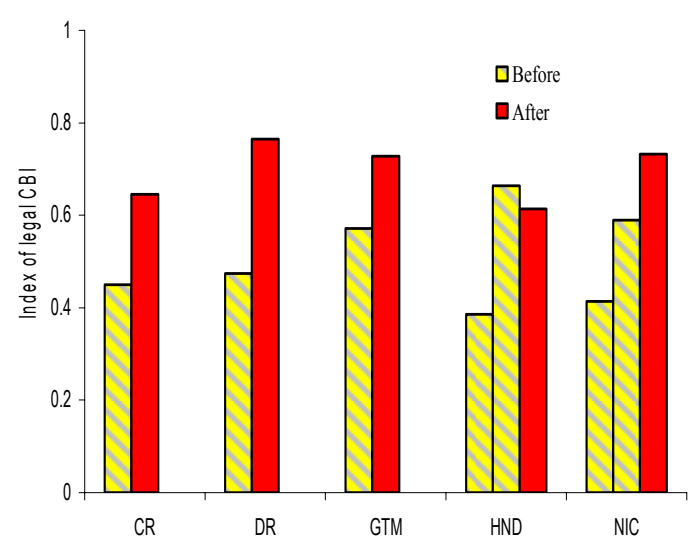

Figure 4. Legal Central Banks Independence (All Latin America)

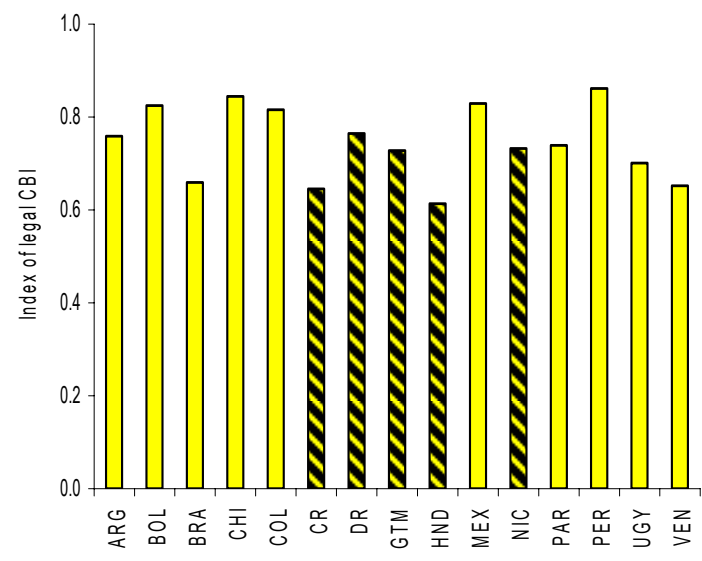

A cluster analysis allows us to confirm that the major institutional weaknesses effectively relate to political autonomy and policy mandate. When the index of central bank independence is broken down into the five main criteria described above, the results show

\footnotetext{
${ }^{10}$ As an exception, Honduras increased significantly the independence of its central bank in 1996, but recently, in 2004, a new law was approved, which implied a slightly backward step.
} 
that these are the criteria explaining why Central American central banks lag behind other central banks in the region (Table 1). However, Central America performs better when measuring the autonomy for policy formulation since other countries in Latin America, such as Argentina, Mexico, and Venezuela, face de jure influences from the executive and legislative branches in the formulation of exchange rate policy. ${ }^{11}$ Another factor underlying this result stems from the provision that gives powers to central banks to restrict public debt expansion, a feature rewarded in the index that is found in most central bank laws in Central America. ${ }^{12}$ On the other hand, both groups of countries rank nearly even in terms of restrictions on lending and accountability provisions.

Table 1. Central Banks' Legal Independence as of 2005

(Central America versus South America and Mexico)

\begin{tabular}{lcc}
\hline & South America and Mexico & Central America \\
\hline Total index */ & $\mathbf{0 . 7 6 9}$ & $\mathbf{0 . 6 9 7}$ \\
Political autonomy (1) & 0.759 & 0.318 \\
Central bank mandate (2) & 0.800 & 0.650 \\
Monetary policy formulation (3) & 0.720 & 0.896 \\
Central bank lending (4) & 0.753 & 0.804 \\
Accountability (5) & 0.875 & 0.800 \\
\hline
\end{tabular}

$* /$ Total index $=0.20 *(1)+0.15 *(2)+0.15 *(3)+0.40(4)+0.10(5)$. See Jácome and Vázquez (2005)

to know the categories behind each criterion and the rationale for the weight assigned to them.

The different degrees of legal central bank independence seem to be factored into inflation performance in Latin America. As shown in Table 2, Central America features lower and more stable inflation following the institutional reform of monetary policy, except for the Dominican Republic, where the systemic banking crisis disrupted monetary policy management. More generally, as shown by Jácome and Vázquez (2005), there is empirical evidence of a negative relationship between legal central bank independence and inflation at a regional level during a period that includes pre and post-reform years.

\footnotetext{
${ }^{11}$ While, in practice, this distortion is less of a problem when countries have in place a flexible exchange ratelike in Mexico - it still restricts central banks' autonomy because they cannot design independently a policy of international reserves' accumulation, which indirectly affects exchange rate management.

12 This criterion is a modified approach of the one included in Cukierman's index.
} 
Table 2. Inflation performance in Central America

(Before and after the reform)

\begin{tabular}{lrccc}
\hline & \multicolumn{2}{c}{ Pre-reform (10 years before) } & \multicolumn{2}{c}{ Post-reform (up to 10 years after) } \\
& \multicolumn{1}{c}{ Mean } & Standard deviation & Mean & Standard deviation \\
\cline { 2 - 5 } Costa Rica & 18.21 & 5.71 & 11.51 & 1.61 \\
Dominican Repub. & 7.29 & 2.38 & 27.70 & 23.63 \\
Guatemala & 8.48 & 2.27 & 7.32 & 1.81 \\
Honduras & 23.13 & 19.64 & 10.95 & 4.01 \\
Nicaragua & 1053.74 & 2440.49 & 7.68 & 2.80 \\
\hline
\end{tabular}

Nonetheless, Central American central banks seem to be less successful in containing inflation pressures from negative shocks. Based on the developments stemming from the recent oil shock, we claim that more autonomous central banks have better chances of preserving inflation under control under adverse circumstances. The rationale for this hypothesis derives from the credibility that more autonomous central banks enjoy with respect to their commitment to maintain inflation in check even under adverse conditions. To support this view, we provide soft evidence that central bank independence or autonomy in Latin America did matter in coping with the inflationary effects of the recent oil shock.

By comparing central banks' autonomy and inflation in the region before and during the worse of the oil crisis, it seems that more autonomous institutions have been in a stronger position to weather the inflationary effects of the oil shock. Figures 5 and 6 portrait the correlation between central banks' autonomy and inflation in Latin America during the periods 2000-2003 and 2004-2005, where the latter captures the worst of the oil shock. ${ }^{13}$ The charts show a much stronger negative correlation during the crisis years, when the credibility of central banks were at stake - as central banks struggled to prevent a high pass-through from rising oil prices to domestic inflation.

In particular, inflation surged more in Central America than in most countries in the region with more independent, and hence, more credible central banks. ${ }^{14}$ This outcome cannot be explained because the Central American economies are oil importers and shifted the whole increase in oil prices into domestic fuel prices. In fact, many countries in the region applied the same policy rule and yet they have achieved a better inflation performance. For instance, while Chile, Colombia, and Peru - with the most independent central banks in the regionallowed a higher pass-through from world oil prices to domestic fuel prices, The increase in fuel prices was not factored into the consumer price index as much as in the Central

\footnotetext{
${ }^{13}$ Central America exhibits the highest average inflation in Latin America in 2004-2005-except for Venezuela, with the Dominican Republic performing as an outlier due to the effects of the 2003 banking crisis.

14 The thrust of this argument prevails when we exclude the Dominican Republic from the charts, which is explained, in part, because central banks in countries, like Colombia, Mexico, Chile in 2004, and Peru in 2005, continued making progress in abating inflation despite the adverse effects of the oil shock.
} 
American economies. ${ }^{15}$ Why? Because, although all countries accommodated the first round effect from the oil shock, central banks in the three South American countries better managed to mitigate the impact on inflation resulting from the second round effect. This may be attributed to a more effective conduct of monetary policy against inflation and/or to stronger policy credibility, which is associated with central banks' independence.

Figure 5. Inflation and Legal Central Banks' Independence in Latin America. 2000-2003

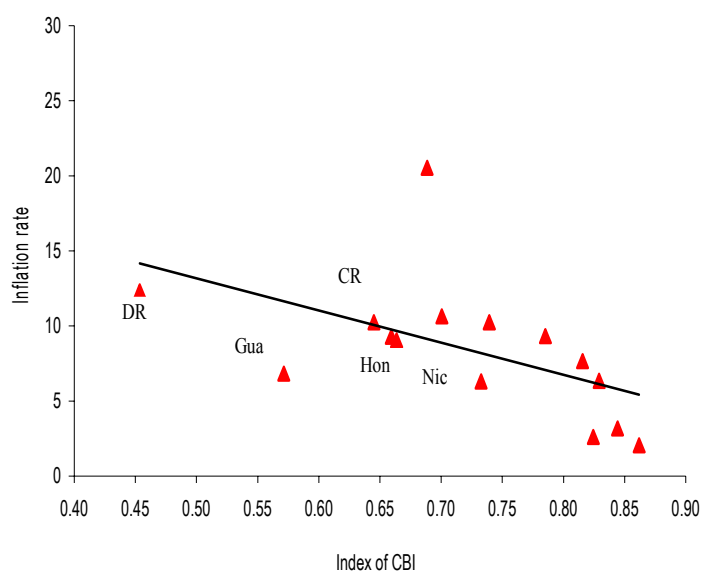

Figure 6. Inflation and Legal Central Banks' Independence in Latin America. 2004-2005

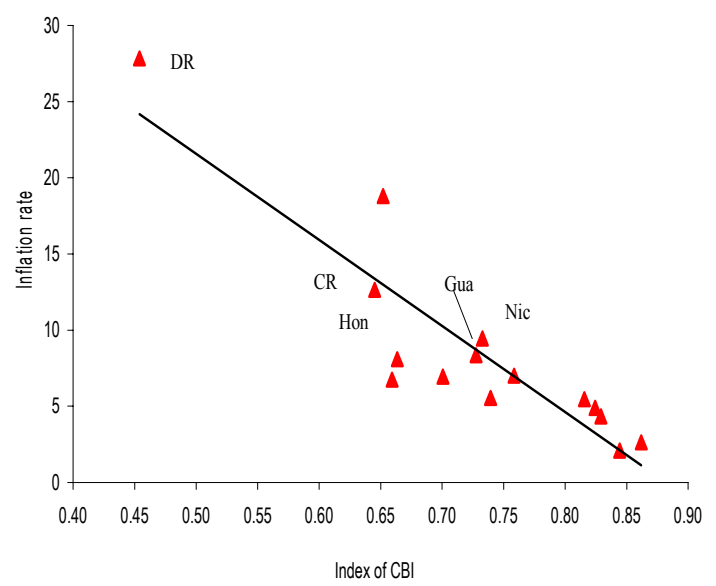

\section{Characterizing Monetary Policy: A Preliminary View}

Despite being small and open economies and having similar trade partners, the Central American countries have adopted different monetary policy regimes. According to the answers provided by their central banks to the questionnaire sent in preparation for this study (see Appendix II), Costa Rica, Honduras, and Nicaragua claim to follow an exchange rate targeting regime. On the other hand, the Dominican Republic and Guatemala allow the exchange rate to adjust - although, in practice, with limitations - and claim to be money and inflation targeters, respectively. This section discusses the main features characterizing the formulation and implementation of monetary policy in the five countries and takes a first look at the data to support their characterization.

To better understand how monetary policy is formulated and executed under each policy regime, we base our analysis on a taxonomy of monetary policy strategies that encompass the three policy modalities in Central America (Table 3). This taxonomy provides a simple analytical framework to characterize the nature of monetary policy regimes and their associated operational arrangements. It is also a useful toolkit to examine the links that in theory exist between monetary policy goals, the corresponding intermediate targets, and the

\footnotetext{
${ }^{15}$ According to the IMF's Western Hemisphere Department, the pass-through to domestic gasoline prices during 2003-2005 in Chile, Colombia, and Peru was higher than in all the countries in our sample, except for the Dominican Republic.
} 
operational arrangements supporting monetary policy implementation. The key notion behind this taxonomy is that targeting money and inflation is consistent with a strategy of allowing the exchange rate to work as the main absorber in response to policy-induced or exogenous shocks, whereas exchange rate targeting relies on international reserves as its primary shock absorber. In addition, although money and inflation targeting share the same primary goal, they differ on what are the intermediate and operational targets they use to achieve their final policy goal. In turn, exchange rate targeting typically assigns priority to the competitiveness of tradable activities as the main policy objective and relies on the real exchange rate and the rate of crawl as intermediate and operational targets, respectively.

Table 3. Taxonomy of Monetary Policy Strategies

\begin{tabular}{lccc}
\hline & Monetary targeting & $\begin{array}{c}\text { Exchange rate } \\
\text { targeting }\end{array}$ & Inflation targeting \\
\hline $\begin{array}{l}\text { Final policy goal } \\
\text { Secondary policy goal }\end{array}$ & Inflation & $\begin{array}{c}\text { Competitiveness } \\
\text { Inflation }\end{array}$ & $\begin{array}{c}\text { Inflation } \\
\text { Competitiveness }\end{array}$ \\
Intermediate target & Money supply & Real exchange rate & Forecasted inflation \\
Operational target & Money base & Rate of crawl & Overnight interest rate \\
$\begin{array}{l}\text { Primary shock absorber } \\
\text { Secondary shock absorber }\end{array}$ & $\begin{array}{c}\text { Nominal exchange rate } \\
\text { Real in interest rate }\end{array}$ & $\begin{array}{c}\text { International reserves } \\
\text { Real interest rate }\end{array}$ & $\begin{array}{c}\text { Nominal exchange rate } \\
\text { Real interest rate }\end{array}$ \\
\hline
\end{tabular}

\section{A. Formulation and Implementation of Monetary Policy in Central America}

Against this backdrop and regardless of the monetary strategy chosen, all countries in Central America share a common analytical policy framework, namely financial programming, which serve as the basis for the formulation and implementation of monetary policy. ${ }^{16}$ Central banks identify an inflation target for the corresponding calendar year, and project accordingly the performance of monetary aggregates and define seasonal targets. They adjust monetary policy should deviations from those targets occur. As a special case, Nicaragua claims to target inflation by using the exchange rate crawl as its nominal anchor-or its intermediate target - with the support of a given amount of international reserves to ensure the viability of the exchange rate regime. Interest rate and monetary aggregates are left as shock absorbers. In turn, Guatemala combines financial programming with an inflation targeting framework, and hence, they adjust a short term interest rate in light of the performance of a decision index called "synthetic index," which comprises 10 criteria, including several monetary aggregates, different measures of projected and expected inflation, a Taylor rule, and an interest parity condition.

Regarding policy formulation and with the aim of shaping operational autonomyestablished in the new central bank charters - most countries in Central America have created

\footnotetext{
${ }^{16}$ See Appendix II for specifications about monetary policy in each country.
} 
open market operation committees. This new institutional arrangement is intended to strengthen and speed up short-term policy responsiveness and separate the execution from the formulation of monetary policy - the latter typically a responsibility of central bank boards in these countries. This reform is particularly important in Central America, given the limited political independence of central banks (see Section II). Yet, the institutional reform has not borne all its fruit given that the conduct of monetary policy exhibits important flaws as we discuss below.

The main instrument used in monetary policy implementation is open market operations, although changes in reserve requirements are also used from time to time. Open market operations are used to steer monetary aggregates within the limits established in central banks' financial programming. In practice, however, the effectiveness of open market operations is undermined because they are not executed under market premises. In particular, interest rates are not allowed to adjust to reflect market preferences and expectations, and rather, central banks use cut-off rates that restrain interest rate increases either because of potential political pressures that see such increases as hindering economic growth, or due to the limitations imposed by the already-weak financial position of most central banks. ${ }^{17}$ As central banks' operating losses become an increasing constraint, markets may have doubts about the long-term ability of central banks to conduct monetary policy and preserve price stability. In addition to using open market operations as a policy instrument, in the recent past, central banks in Central America - except Guatemala - have also used changes in reserve requirements to moderate excessive liquidity abundance. Given that bank reserves are not remunerated, central banks feel tempted to use reserve requirements as a costless policy instrument to mop-up large amounts of liquidity.

Another important flaw of central banks' monetary implementation is the lax management of short-term liquidity. While most central banks conduct some form of liquidity projections, they are unable of maintaining a tight control of systemic liquidity, and rather liquidity surplus prevails in all countries. The preferred modality of liquidity projections in Central America is based on an extrapolation of financial programming, which gives central banks an idea of the existing systemic liquidity on a weekly basis vis-à-vis the projected trends of monetary aggregates. Based on this information, central banks get a sense of the needs of injecting or extracting liquidity, which not necessarily materialize because of pitfalls in conducting open market operations as argued above. The described situation opposes to what other central banks in the region do (like in Brazil and Mexico), as they generally maintain the system short and provide systemic liquidity according to their monetary policy stance.

At the same time, most central banks in Central America have recently adopted a policy rate with the aim of boosting the effectiveness of monetary policy, but this has been ineffective. Costa Rica, the Dominican Republic, Guatemala, and Honduras recently established a shortterm interest rate, and are using it as an operational instrument and to signal changes in the monetary policy stance and guide market expectations. In practice, however, the policy rate is playing little or no role, as its changes are rarely followed by market interest rates (Figure

\footnotetext{
${ }^{17}$ In Central America, central bank deficits are as high as more than 1 percent of GDP in most countries.
} 
7). This is not surprising in countries with exchange rate targeting because, by definition, it is the rate of devaluation the variable that signals and feed inflation expectations and because, in principle, the exchange rate peg limits central banks' capacity to fully control liquidity, which makes difficult to align central bank and commercial banks' interest rates.

Figure 7. Policy Rates versus Banks’ Lending Rates
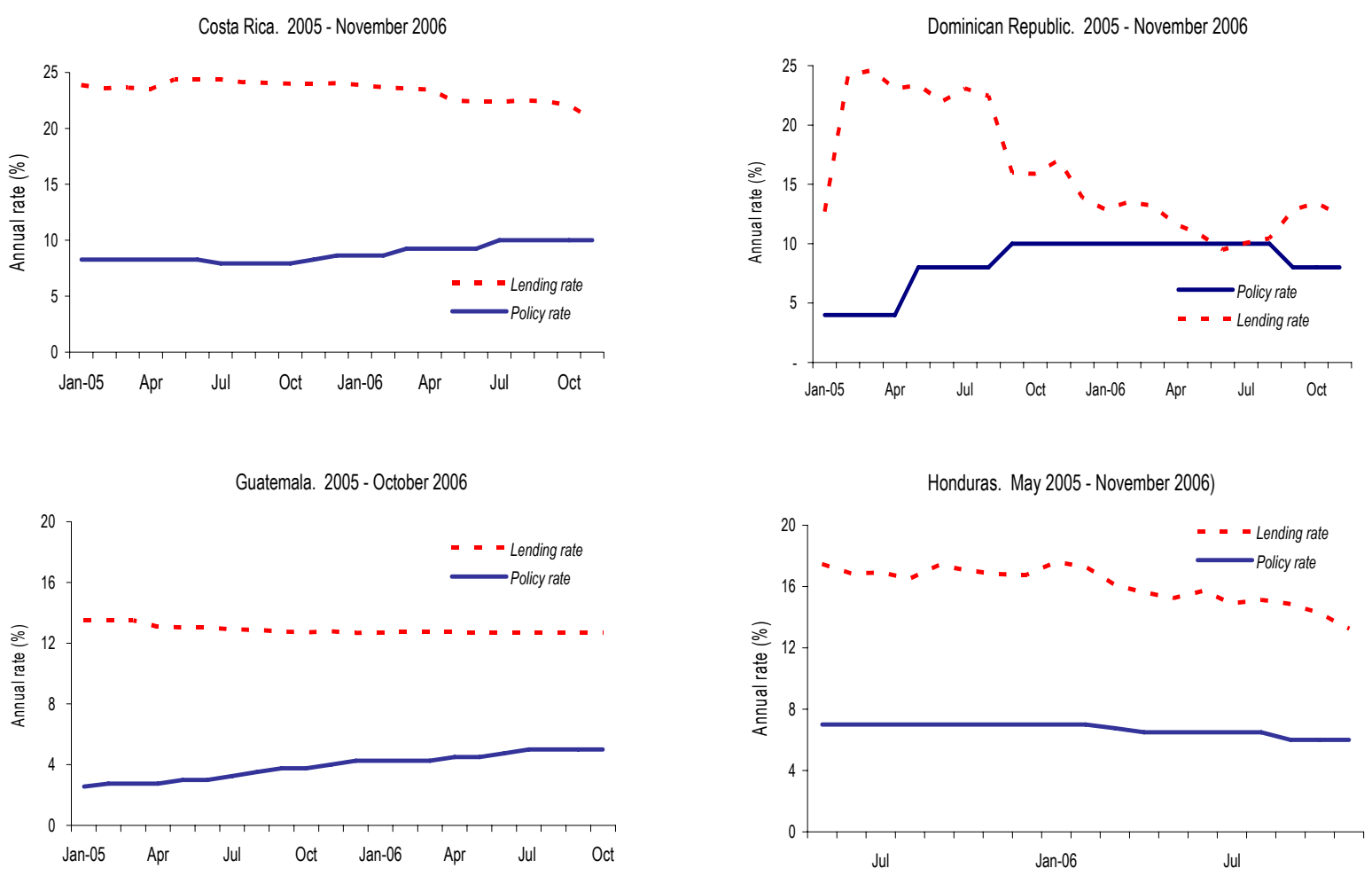

Source: Central banks from each country

The lack of central banks' proper liquidity management and the shallowness of money markets help to explain the disconnection between central banks' policy rates and commercial bank interest rates in countries with flexible exchange rates. On the one hand, in the absence of proper liquidity management central banks' policy rate generally does not reflect the underlying systemic liquidity conditions, and hence, changes in the policy rate are not necessarily followed by market interest rates. On the other hand, the limited development of interbank and money markets, reduces the significance of interest rates and tend to make them more volatile. The large liquidity surpluses observed in the last years in all Central American countries exacerbates the difficulties encountered by central banks to manage systemic liquidity and stifles the development of interbank and money markets. This is because most central banks are reluctant to drain the large liquidity surplus because of their weak financial position, which leaves market participants with long positions, and hence, without the need of trading among each other. In this environment, a meaningful yield curve is absent in all countries, which imposes important limitations on market participant decisions and restricts valuable information to central banks about markets' expectations. 
Moreover, the transmission mechanism of monetary policy is hindered because of the limited effect of central bank policies on aggregate demand and inflation.

\section{B. A First Look at the Data}

A quick look to the volatilities of key monetary variables in each country between 2000 and 2005 shed some light to characterize in practice monetary policy in Central America. The analysis attaches special interest to the performance of exchange rates and international reserves as they implicitly define which variable is targeted and what the main shock absorber is. To obtain a better sense of the information these numbers convey, we compare them to similar computations for other Latin American countries, which include an exchange rate targeter, like Bolivia, and inflation targeters, such as Chile, Colombia, Mexico, and Peru.

On a preliminary basis, we label Costa Rica and Nicaragua, and to less extent Honduras, as exchange rate targeters. As observed in Table 4, Costa Rica indeed features the lowest exchange rate variability among the Central American countries and uses international reserves as the first line of defense to adjust against shocks. This is not surprising because, during the period of analysis, the Central Bank of Costa Rica pre-announced the colón devaluation rate for the following year and rarely made adjustments to the pre-announced path. Unlike the former, the Central Bank of Nicaragua, although targeting the exchange rate, does not allow international reserves to vary significantly; alternatively, it is the real interest rate which seems to work as a shock absorber, which is consistent with the information provided in the answers to the questionnaire. In turn, it is difficult to identify what is the main shock absorber in Honduras.

On the other hand, it appears difficult to characterize the policy regime embraced by the Dominican Republic and, in particular, by Guatemala. These countries feature greater exchange rate flexibility than the other three-although much less than the inflation targeting countries in Latin America - and a volatility of international reserves similar to the one featured by the exchange rate targeters. ${ }^{18}$ On these grounds, Guatemala does not seem to be operating yet as an inflation targeter but rather it approximates more to an exchange rate targeter given the high variability of the international reserves. This conclusion is reinforced as we focus on the last three years, when the standard deviation of the exchange rate depreciation was only 0.20 .

The performance of real interest rates - with respect to contemporaneous inflation-does not exhibit major differences across countries, which suggests that all countries in Central America also use real interest rates as shock absorber. This outcome is not surprising. Most central banks in developing and emerging countries, regardless of their policy regime, seem to adjust interest rates to contribute, either to preserve a high international reserves and mitigate excessive exchange rate volatility — in the exchange rate targeting countries - or to

\footnotetext{
${ }^{18}$ The volatility of international reserves in the Dominican Republic is partly explained by its rapid decline in 2002 as the systemic banking crisis started to unfold.
} 
affect aggregate demand, and hence, the intermediate target - in money and inflation targeting countries.

Table 4. Volatilities of Selected Macroeconomic Variables (Standard deviations 2000-2005)

\begin{tabular}{lccc}
\hline & $\begin{array}{c}\text { Nominal } \\
\text { depreciation }\end{array}$ & $\begin{array}{c}\text { International } \\
\text { reserves (\% change) }\end{array}$ & $\begin{array}{c}\text { Real interest } \\
\text { rates }\end{array}$ \\
\hline & \multicolumn{1}{c}{ Central America and the Dominican Republic } \\
Costa Rica & 0.13 & 7.54 & 2.19 \\
Dominican Rep. 1/ & 1.14 & 9.88 & 3.11 \\
Guatemala 1/ & 0.71 & 6.69 & 1.74 \\
Honduras & 0.16 & 2.92 & 1.42 \\
Nicaragua 1/,2/ & 0.05 & 7.40 & 3.75 \\
& Other selected countries in Latin America \\
Bolivia & 0.27 & 8.43 & 3.67 \\
Chile & 2.51 & 2.62 & 2.60 \\
Colombia & 2.23 & 2.41 & 1.36 \\
Mexico & 1.71 & 2.89 & 2.52 \\
Peru & 0.93 & 3.04 & 4.72 \\
\hline
\end{tabular}

1/ The calculations cover the period 1996-2002 in the Dominican Republic and 2002 onward in Nicaragua, to avoid capturing the effects on monetary variables of their systemic banking crises, whereas in Guatemala, the period starts following once and for all 50 percent increase in international reserves resulting from a large sovereign debt placement that took place by late- 2001 . 2/ For Nicaragua, given the lack of consistent central bank's interest rate series, the 1-month deposit rate in the commercial banks is used as an imperfect substitute.

\section{EMPIRICAL REgularities SuPPORTINg THE CHARACTERIZATION OF MONETARY POLICY}

How does the former characterization of monetary policy can be reconciled with actual central bank policies in Central America? This section addresses this question by estimating central banks' reaction functions and assessing how central banks have reacted in practice to shifts in underlying economic fundamentals, especially inflation, in each country. The main idea behind the proposed analysis is to ascertain whether central banks in Central America work under clear, effective, and predictable rules, which makes them more likely to deliver overtime lower inflation rates.

We also test reaction functions of the exchange rate crawl and the money base. The former is applicable, in particular to countries that feature exchange rate-based stabilization policies, like Costa Rica, Honduras, and Nicaragua, and the latter to the Dominican Republic, although it may also capture the behavior of the Bank of Guatemala during the late 1990s. Expanding the analysis from the standard reaction function based on the interest rate as the 
policy instrument is warranted given the heterogeneity of monetary policy regimes in Central America. ${ }^{19}$

\section{A. Methodology and Data}

We consider a mix of policy instruments to estimate separately several policy reaction functions along the general lines of Taylor (1993), Parrado (2004), and McCallum (1988), respectively, depending on the instrument considered: ${ }^{20}$

$$
\begin{gathered}
i_{t}=(1-\rho) \alpha+(1-\rho) \beta \pi_{t+n}+(1-\rho) \gamma x_{t+m}+\rho i_{t-1}+\varepsilon_{t}, \\
\Delta e_{t}=(1-\rho) \alpha+(1-\rho) \beta \pi_{t+n}+(1-\rho) \gamma x_{t+m}+\rho \Delta e_{t-1}+\varepsilon_{t}, \\
\Delta m_{t}=(1-\rho) \alpha+(1-\rho) \beta \pi_{t+n}+(1-\rho) \gamma x_{t+m}+\rho \Delta m_{t-1}+\varepsilon_{t},
\end{gathered}
$$

where $i$ is a policy interest rate, typically a short-term interest rate, $\pi$ is the inflation rate, $x$ is the output gap, $m$ is a monetary aggregate defined as the intermediate target (typically the money base), and $e$ is the exchange rate. We estimate the reaction functions using the Generalized Method of Moments (GMM).

Equation (1) provides the critical analytical framework to assess central banks' reaction functions. Regardless of their monetary regime, central banks tend to use interest rate as an instrument to tackle inflation, influence economic activity, and even affect developments in the foreign exchange rate market. In particular, monetary-based policy regimes adjust interest rates to affect monetary aggregates and indirectly inflation. In turn, central banks that have adopted exchange rate crawls use interest rates as a policy instrument to defend the peg and to protect international reserves in times of financial turbulence. Inflation targeting countries adjust the interest rate as a policy variable to guide expectations and steer actual inflation toward forecasted inflation.

Equation (2) usually provides valuable information about countries using an exchange rate crawl as a policy instrument, but it may also be relevant when it comes to floating exchange regimes. Typically, this equation assumes that the rate of crawl is regularly adjusted to compensate for inflation differentials with respect to its "target." A clear example of this policy approach is found in Singapore, where the monetary authorities presume that small open economies cannot manage interest rates and only have control over the exchange rate. ${ }^{21}$

\footnotetext{
${ }^{19}$ Corbo (2002) finds that, in setting their policy rates, central banks consider not only inflation but also other objectives such as output and the exchange rate.

${ }^{20}$ For further details see Appendix III.

${ }^{21}$ In particular, the Monetary Authority of Singapore uses explicitly a trade weighted index to conduct monetary policy and offset fluctuations both in inflation and output. See Parrado (2004).
} 
In some countries, this policy rule may also serve to compensate for differentials between actual and potential output. Under this approach, this policy rule may not be as relevant in Central America. While targeting the exchange rate may give some signals about the longterm direction of exchange rate policy, in the short run this information has less of a foundation in Costa Rica and Nicaragua, as their central banks tend to favor a predictable path for the exchange rate, and hence do not use it as a policy instrument on a short-term basis. Honduras, in turn, can adjust the rate of crawl on a short-term basis, and hence, has the potential for using it as a policy instrument either to moderate inflation or to target a real exchange rate. On the other hand, equation (2) may also be relevant to gauge whether central banks using flexible exchange rate regimes de facto care about the competitiveness of tradable activities - by means of interventions in the foreign exchange market.

The specification in equation (3) is tailored to capture the policy reaction of central banks that directly adjust monetary aggregates in response, for example, to inflation pressures. Thus, it is applicable to central banks that have in place a flexible exchange rate regime, which makes room for an exogenous management of monetary aggregates. Nonetheless, the experiment may also apply to exchange rate targeters (Honduras and Nicaragua), which have negotiated successive economic programs with the IMF during the period of analysis. The policy framework associated to these economic programs envisages that central banks should tighten monetary policy to cope with inflation pressures.

As a baseline specification, we consider output and inflation as the standard targets of monetary policy in the reaction functions of central banks as it is standard in the literature. However, depending on the reaction function, we also include other objectives such as the exchange rate, the real exchange rate, and international reserves into the baseline specification and analyze the behavior of some key model parameters. In the baseline specification, we pay special attention to the parameters associated with inflation and to less extent to output. This is because, as discussed before, fighting inflation is a key feature in Central American central banks' mandate whereas output stability or fostering economic growth is not an objective in their charter any more.

The analysis is based on monthly data for $1996-2005 .^{22}$ The selected period corresponds to the time span that follows the inception of the new institutional setting that granted most central banks enhanced operational autonomy. Choosing this period allows for isolating the analysis from the first half of the 1990s, when Central America experienced a steep decrease in inflation, which would probably distort the empirical analysis. To control for the adverse effects of systemic banking crises on monetary policy, we included dummy variables. In particular, the estimations control for the expansionary monetary stance associated with central banks' involvement in the full-fledged banking crises that hit Nicaragua in 2001-02 and the Dominican Republic in 2003. In addition, to test whether the Bank of Guatemala has

\footnotetext{
${ }^{22}$ The data for the Dominican Republic was collected on a quarterly basis, given that this country lacks a monthly measure of economic activity.
} 
been lately formulating monetary policy as an inflation targeter we run a second experiment considering the period late-2001 to $2005 .^{23}$

The data series were obtained directly from each central bank. The quality of the data is rather good, except for the monthly series of economic activity, which is an imperfect substitute of a gross domestic product series. On a country basis, a consistent series for central bank interest rate in Nicaragua is not available, and hence, we used the one month deposit interest rate in commercial banks as an imperfect substitute. In addition, measures of output gap are not available, and hence, output is used directly. With these caveats in mind, we should be cautious in being too conclusive when interpreting the outcome of the empirical assessment of the central bank reaction functions in Central America, particularly when it comes to analyzing the response of policy instruments to output behavior.

\section{B. Estimations}

The results stemming from this quantitative analysis shed some light about central banks' actual policy implementation. In particular, they show that, regardless of the monetary regime, all central banks respond by raising interest rates in light of inflation pressures. ${ }^{24}$ However, the magnitude of the response differs across countries. The estimations also stress that some central banks simultaneously seek to preserve exchange rate stability - which can be a source of policy conflicts - and reveal the difficulties of effectively targeting the real exchange rate. Finally, the results suggest that most central banks tighten money to tackle inflation, regardless of whether they target money or the exchange rate.

\section{Interest rate reaction functions}

Assuming a forward-looking horizon of zero months, the coefficients associated with inflation are positive and statistically significant in all countries. ${ }^{25}$ They indicate that in response to a 1 percent change in inflation, the interest rate is modified in the range of 0.6 to nearly 2 percent depending on each country (Table 5). The coefficient associated with inflation is higher than 1 in Costa Rica and, in particular, in Guatemala - in both samples alike-, which implies that the real interest rate moves in the same direction as the nominal rate. This means that the interest rate is temporarily altered to potentially affect aggregate demand, and thus, inflation (the aggregate demand function is then negatively sloped with

\footnotetext{
${ }^{23}$ While the Bank of Guatemala claims to have gradually started the transition to inflation targeting since 2000, we chose to artificially divide the two periods in connection with a large sovereign debt placement that took place by late-2001, which produced a once and for all 50 percent increase in international reserves, and hence a structural brake in the series.

${ }^{24}$ The assumption behind these experiments is that central banks adjust autonomously interest rates and not automatically as a result of market trends.

${ }^{25}$ This assumption implies that $\mathrm{n}=\mathrm{m}=0$ in the base line rule (1). While it is possible that central banks do not observe both data on inflation and output simultaneously, in particular because the latter is observed with a short lag, the current analysis assumes that central banks have perfect foresight in terms of output. In an augmented policy rule that includes, for example, the real exchange rate, the same assumption applies.
} 
respect to the inflation rate). At the other extreme, the value of the inflation coefficient in the Dominican Republic, Nicaragua, and Honduras suggests that, in practice, there is a partial accommodative reaction as the increase in nominal interest rates in response to inflationary pressures is insufficient to prevent the real interest rate from falling. This is not surprising in exchange rate targeting countries, where the rate of devaluation is indeed central bank's operational variable. However, it may also be that central banks in these countries also use other policy instruments to cope with inflation pressures.

Table 5. Interest Rate Reaction Function of Central Banks, 1996-2005 ${ }^{1}$

\begin{tabular}{lccccc}
\hline & $\begin{array}{c}\text { Lagged } \\
\text { Instrument }\end{array}$ & Constant & Inflation & Output & $\begin{array}{c}\text { Exchange } \\
\text { Rate }\end{array}$ \\
\hline Costa Rica & $1.05^{*}$ & -0.16 & $1.25^{*}$ & -0.27 & $2.53^{*}$ \\
Guatemala-1 & $(90.03)$ & $(2.17)$ & $(3.21)$ & $(1.07)$ & $(3.98)$ \\
Guatemala-2 & $0.94^{*}$ & -0.11 & $1.98^{*}$ & $1.11^{*}$ & $0.66^{*}$ \\
& $(155.98)$ & $(2.88)$ & $(5.32)$ & $(2.14)$ & $(5.68)$ \\
Honduras & $0.96^{*}$ & -0.06 & $1.93^{*}$ & -0.21 & $0.48^{*}$ \\
& $(476.23)$ & $(3.67)$ & $(9.17)$ & $(0.69)$ & $(4.98)$ \\
Nicaragua & $0.93^{*}$ & -0.01 & $0.62^{*}$ & $0.62 *$ & $0.89 *$ \\
& $(72.89)$ & $(0.46)$ & $(1.72)$ & $(4.99)$ & $(3.38)$ \\
Dominican Republic $^{2}$ & $0.96^{*}$ & -0.06 & $0.71 *$ & -0.02 & $0.73 *$ \\
& $(87.62)$ & $(1.83)$ & $(2.18)$ & $(0.17)$ & $(5.10)$ \\
& 0.40 & -0.07 & $0.70 *$ & $2.19 *$ & 0.03 \\
& $(1.41)$ & $(0.77)$ & $(4.36)$ & $(2.05)$ & $(0.25)$ \\
\hline
\end{tabular}

t-statistics in parenthesis

* Coefficients are statistically significant at 5 percent level.

Guatemala-1 is based on the 1996-2005 period and Guatemala-2 corresponds to the late-2001 to 2005 period, when the Bank of Guatemala started to formulate and implement monetary policy as an inflation targeter.

${ }^{1}$ Estimations for the Dominican Republic are based on quarterly data.

${ }^{2}$ Dummy variables are used to control for banking crises periods.

The estimations also show that central banks, except for the Dominican Republic, react to cap exchange rate swings. This reaction has at least two possible readings-depending on the monetary policy regime in each country_-, which eventually point to a scenario of "fear of floating." In an environment of exchange rate targeting (Costa Rica, Honduras, and Nicaragua), central banks may increase interest rates in response to exchange rate unexpected devaluations in order to preserve a covered interest parity condition and, if necessary, defend the pre-announced exchange rate path-which could otherwise cause major disturbances in the foreign exchange market and a negative impact on market participants' balance sheets. Alternatively, when it comes to money and inflation targeting, this reaction may show that central banks also care about exchange rate stability.

The affection that central banks hold for preserving the external stability of their currencies could be justified on many possible fronts. When the country is experiencing an appreciation trend, the central bank may seek to reverse this trend fundamentally to avoid hurting the external competitiveness of tradable activities. On the other hand, averting major foreign exchange depreciations may be due to central banks' perception that the exchange rate pass- 
through to prices is significant. This is a plausible explanation in small and very open economies, like in Central America, where exchange rate performance has a great impact on price formation. An alternative rationalization is that central banks assign a relatively higher weight to the exchange rate to maintain trade competitiveness and even financial stability. Regarding the latter, Calvo and Reinhart (2002) argue that the "fear of floating" found in a number of emerging markets is explained by the high risk premium they have to pay because of their low institutional and policy credibility. The resistance to floating the exchange rate may be predominantly high in countries with shallow markets that are subject to herd behavior. Also, financial imperfections such as a large external debt or debt indexed to the exchange rate, as in Nicaragua and Costa Rica, make the case for preventing exchange rate devaluations. Eichengreen (2002) and Goldstein and Turner (2004) have recently highlighted the adverse consequences of exchange rate depreciations in countries with a high degree of dollarization. Sharp currency depreciations can cause widespread bankruptcies as a result of their adverse effect on unhedged borrowers. This rather unconventional and contractionary impact of exchange rate depreciations makes it necessary for central banks to raise interest rates defensively against major exchange rate shocks.

Because of the caveats associated with measures of output in Central America, it is worth cautiously mentioning the seemingly counter-cyclical role of some central banks. Guatemala, Honduras, and, in particular, the Dominican Republic, seem to reduce interest rates to confront a slowdown in economic activity. In addition, central banks in Nicaragua, the Dominican Republic, and especially Costa Rica, appear to raise interest rates to safeguard the stability of international reserves (not reported). One can understand this behavior as an effort to underpin exchange rate stability, which in countries with high capital mobility critically hinges on preserving an appropriate level of international reserves.

\section{Exchange rate crawl reaction function}

While the estimates of this reaction function have generally resulted in unstable and rather erratic coefficients, depending on the combination of endogenous variables, some interesting results are worth mentioning from our experiments. ${ }^{26}$ We run a baseline scenario with a forward-looking horizon of zero months, except for the real exchange rate, which is lagged one period. ${ }^{27}$ The estimates show that, among the exchange rate targeters, only Cost Rica has an exchange rate policy that is able to partially preserve the competitiveness of domestic activities given that the coefficient associated with the inflation rate is statistically significant although smaller than one (Table 6). Strikingly, the results also show that Guatemala features an accommodative exchange rate policy with respect to inflation, which points in the direction of a central bank that cares about tradable activities, in particular during the

\footnotetext{
${ }^{26}$ Even at a conceptual level, the impact of changes in the rate of crawl on inflation and output volatility is unclear and depends on the characteristics of the monetary transmission channels. Should the interest rate effect dominate the exchange rate effect, at least in the short run, a demand shock will require an increase in the rate of crawl (that allows a rise in interest rates). A reduction in the rate of crawl would otherwise be appropriate.

27 The real exchange rate is lagged in order to avoid collinearity with the nominal exchange rate. A one-month lag reflects the delay in the availability of this information at the Central American central banks.
} 
transition to inflation targeting - with a coefficient larger than one. Thus, an accommodative exchange rate policy in response to inflation in Guatemala may cast doubts on market participants about the true central banks' primary objective. Seeking to simultaneously preserve the internal and external value of domestic currencies may become mutually incompatible, particularly when the country experiences exchange rate appreciation trends.

Table 6. Exchange Rate Crawl Reaction Function, 1996-2005

\begin{tabular}{lccccc}
\hline & $\begin{array}{c}\text { Lagged } \\
\text { Instrument }\end{array}$ & Constant & Inflation & Output & $\begin{array}{c}\text { Real Exchange } \\
\text { Rate }(\mathrm{t}-1)^{2}\end{array}$ \\
\hline Costa Rica & $0.94^{*}$ & $0.02^{*}$ & $0.39^{*}$ & $0.55^{*}$ & 0.06 \\
Guatemala-1 & $(129.02)$ & $(1.41)$ & $(3.71)$ & $(8.66)$ & $(1.63)$ \\
Guatemala-2 & $0.65 *$ & 0.03 & -0.18 & $0.92 *$ & $-0.69^{*}$ \\
& $(9.18)$ & $(1.62)$ & $(0.74)$ & $(5.40)$ & $(9.08)$ \\
Honduras & $0.51 *$ & $-0.03 *$ & $1.16^{*}$ & $-1.21 *$ & $-0.77^{*}$ \\
& $(11.60)$ & $(3.65)$ & $(13.44)$ & $(10.52)$ & $(17.26)$ \\
Nicaragua & $1.04 *$ & 0.12 & -0.78 & 0.25 & 0.16 \\
& $(49.35)$ & $(1.12)$ & $(0.63)$ & $(1.47)$ & $(0.35)$ \\
Dominican Republic $^{3}$ & $1.01 *$ & 0.10 & -0.15 & 0.20 & -0.35 \\
& $(187.74)$ & $(1.24)$ & $(0.18)$ & $(0.47)$ & $(1.49)$ \\
& $0.69 *$ & 0.54 & -2.82 & $-3.90 *$ & 2.33 \\
& $(2.76)$ & $(1.04)$ & $(1.07)$ & $(0.90)$ & $(1.34)$ \\
\hline
\end{tabular}

t-statistics in parenthesis

* Coefficients are statistically significant at 5 percent level.

Guatemala-1 is based on the 1996-2005 period and Guatemala-2 corresponds to the late-2001 to 2005 period, when the

Bank of Guatemala started to formulate and implement monetary policy as an inflation targeter.

${ }^{1}$ Estimations for the Dominican Republic are based on quarterly data.

${ }^{2} \mathrm{~A}$ fall in the real exchange rate implies an appreciation and vice versa.

${ }^{3}$ Dummy variables are used to control for banking crises periods.

The results also show that maintaining a stable real exchange rate is a difficult endeavor. This may be due to the use of a backward-looking rule in announcing the future path of the peg in an environment of unstable inflation, which makes it more difficult to target a given real exchange rate. Strikingly, by managing the exchange rate more flexibly - although intervening in the exchange rate market — the Bank of Guatemala has preserved a real exchange rate parity, which signals its concern for an exchange rate that is either appreciated or depreciated in real terms. The failure of most central banks in Central America to maintain a given real exchange rate level is in accordance with the conventional wisdom that claims that real exchange rates are endogenous in the short run.

\section{Money base reaction function}

The results from the money reaction function are mixed for both money and exchange rate targeters (Table 7). Among the former, only Bank of Guatemala appears to tighten the money base to cope with inflation pressures, whereas the coefficient of inflation in the Dominican Republic has the expected sign but is not statistically significant. The value of the coefficients also suggests that the use of the money base to tackle inflation pressures has declined in Guatemala during the transition to inflation targeting. As for the exchange rate 
targeters, despite the limitations that targeting the exchange rate impose on the control of monetary variables, the central banks in Nicaragua and, in particular in Honduras, seem to have a strong capacity to tighten the money base in response to inflation.

Table 7. Central Banks' Money Reaction Function, 1996-2005 ${ }^{1}$

\begin{tabular}{lccccc}
\hline & $\begin{array}{c}\text { Lagged } \\
\text { Instrument }\end{array}$ & Constant & Inflation & Output & $\begin{array}{c}\text { Exchange } \\
\text { Rate }\end{array}$ \\
\hline Costa Rica & $0.90^{*}$ & $-0.40^{*}$ & 2.25 & 0.65 & $3.34 *$ \\
Guatemala-1 & $(52.84)$ & $(2.74)$ & $(1.61)$ & $(0.78)$ & $(1.83)$ \\
& $0.87^{*}$ & 0.10 & $-2.38^{*}$ & $7.95 *$ & $-0.82 *$ \\
Guatemala-2 & $(22.24)$ & $(1.23)$ & $(2.73)$ & $(3.78)$ & $(2.22)$ \\
& $0.57^{*}$ & $0.19 *$ & $-0.79 *$ & $-1.16^{*}$ & $0.51 *$ \\
Honduras & $(12.90)$ & $(16.19)$ & $(6.02)$ & $(2.31)$ & $(4.98)$ \\
& $0.93 *$ & $0.67 *$ & $-6.99 *$ & $-3.26^{*}$ & $5.39 *$ \\
Nicaragua & $(43.85)$ & $(3.37)$ & $(2.75)$ & $(2.54)$ & $(2.84)$ \\
& $0.54 *$ & $0.21 *$ & $-1.20 *$ & $-0.41 *$ & $1.26 *$ \\
Dominican $^{2}$ & $(10.74)$ & $(5.77)$ & $(2.94)$ & $(3.13)$ & $(4.88)$ \\
& $0.38^{*}$ & 0.01 & 0.23 & 1.33 & 0.23 \\
& $(0.98)$ & $(0.05)$ & $(0.40)$ & $(0.64)$ & $(0.85)$ \\
\hline
\end{tabular}

t-statistics in parenthesis

* Coefficients are statistically significant at 5 percent level.

Guatemala-1 is based on the 1996-2005 period and Guatemala-2 corresponds to the late-2001 to 2005 period, when the Bank of Guatemala started to formulate and implement monetary policy as an inflation targeter.

${ }^{1}$ Estimations for the Dominican Republic are based on quarterly data.

${ }^{2}$ Dummy variables are used to control for banking crises periods.

One possible explanation to this puzzling outcome is that the assumption of perfect capital mobility is less binding in Honduras and Nicaragua, which makes room for achieving some influence on monetary aggregates. This explanation is mostly relevant for Honduras, where the surrender requirement of foreign currency to the central bank inhibits the normal flow of foreign currency transactions. In addition, in both countries the money market is shallow, which restricts arbitrage conditions. Tightening monetary aggregates to cope with inflation pressures in Honduras and Nicaragua, despite being exchange rate targeters, may also be associated with IMF programs, which have been in effect in these two countries during most of the period of analysis. As noted, standard IMF programs require central banks to observe quarterly monetary targets as performance criteria.

\section{COnCluding Remarks}

Most Central American countries have succeeded in reducing inflation to the single-digit range. This outcome is not only the result of a drop in inflation in the rest of the world; it also follows from the Central American nations having maintained sound macroeconomic policies and adopted structural reforms over more than 10 years. A key component of this macroeconomic strategy has been to give central banks enhanced autonomy to formulate and execute monetary policy. Today, central banks in Central America, like their peers in the rest of the region, are no longer development banks. They focus their policies on fighting 
inflation, although in some countries the central bank also embraces the parallel objective of preserving the external value of domestic currencies.

Despite the progress achieved by the Central American central banks in reducing inflation, there is no room for complacency. Inflation in most countries is still high by regional and world standards. Moreover, central banks are still in the process of building reputation and credibility, which is expected not only to favor them to reduce further and stabilize inflation, but also to better withstand exogenous events, such as the recent oil shock that shifted inflation in some countries to low two-digit rates.

While all central banks in the region enjoy more solid institutional strength, additional steps should be taken to underpin their credibility and achieve better inflation results. Progress is still necessary in four main areas to: (1) eliminate the latent policy conflict that emerges when monetary policy simultaneously seeks the internal and external stability of the domestic currency; (2) strengthen political autonomy to untie monetary policy horizons from political cycles; (3) grant financial autonomy to reinforce current de jure operational autonomy of central banks; and (4) set more rigorous accountability and transparency procedures to bolster the credibility of monetary policy.

Central banks in Central America have made important strives in modernizing monetary operations, but this is also an area where there is room for improvement. While central banks established indirect instruments of monetary policy many years ago, open market operations do not allow for price discovery as interest rates are generally determined exogenously by central banks. As a result, money markets in most countries are still shallow, whereas yield curves are rather artificial and convey meaningless information to both central banks and market participants. In addition, central banks have not been proficient in managing liquidity surplus - currently exacerbated by abundant international liquidity - and hence, changes in short-term central bank interest rates have not been followed by similar changes in commercial bank interest rates.

Tracing central bank reaction functions in Central America allows for establishing a connection between their institutional setting and monetary policy implementation. The quantitative analysis developed in this paper allows us to get a sense of the main thrust of monetary policy in the sample countries. It confirms that central banks, in general, behave by increasing interest rates to curtail inflationary pressures, although with different impetus in each country. In other words, some central banks are raising interest rates less than what is required to tame inflation pressures.

A second empirical regularity is that all central banks, except for the Dominican Republic, also care about the stability of the exchange rate, which may blur their true policy objective. They react by adjusting upward interest rates either to prevent deviations from the targeted purchasing power parity, or to confront pressures on the exchange rate with the aim of mitigating pass-through effects of exchange rate depreciations on prices and because of the so-called "fear of floating." By the same token, these central banks also seem to systematically resist exchange rate appreciations, which would otherwise support 
disinflation. In addition, central banks in Costa Rica and Guatemala exhibit a policy of accommodating inflation trends into exchange rates performance with the aim of preserving the competitiveness of their tradable activities.

The potential policy conflicts facing central banks in Central America are probably undermining markets' confidence in their commitment to price stability. The fact that central banks are unable to deliver a predictable monetary policy and signal at times mutually excluding policy objectives - such as seeking the internal and external value of the currency - may help to understand the perpetuation of an inflation bias in Central America.

While this paper steps up the understanding of monetary policy in Central America, additional analytical work is needed to improve the effectiveness of monetary policy. Areas for further research include: (1) analyzing how the transmission mechanisms of monetary policy work in this region; (2) identifying the most appropriate exchange rate regime applicable to the Central American countries, given their increasing openness and integration with the U.S. economy and he growing remittances from abroad; and (3) defining the most suitable operational framework for monetary policy. 


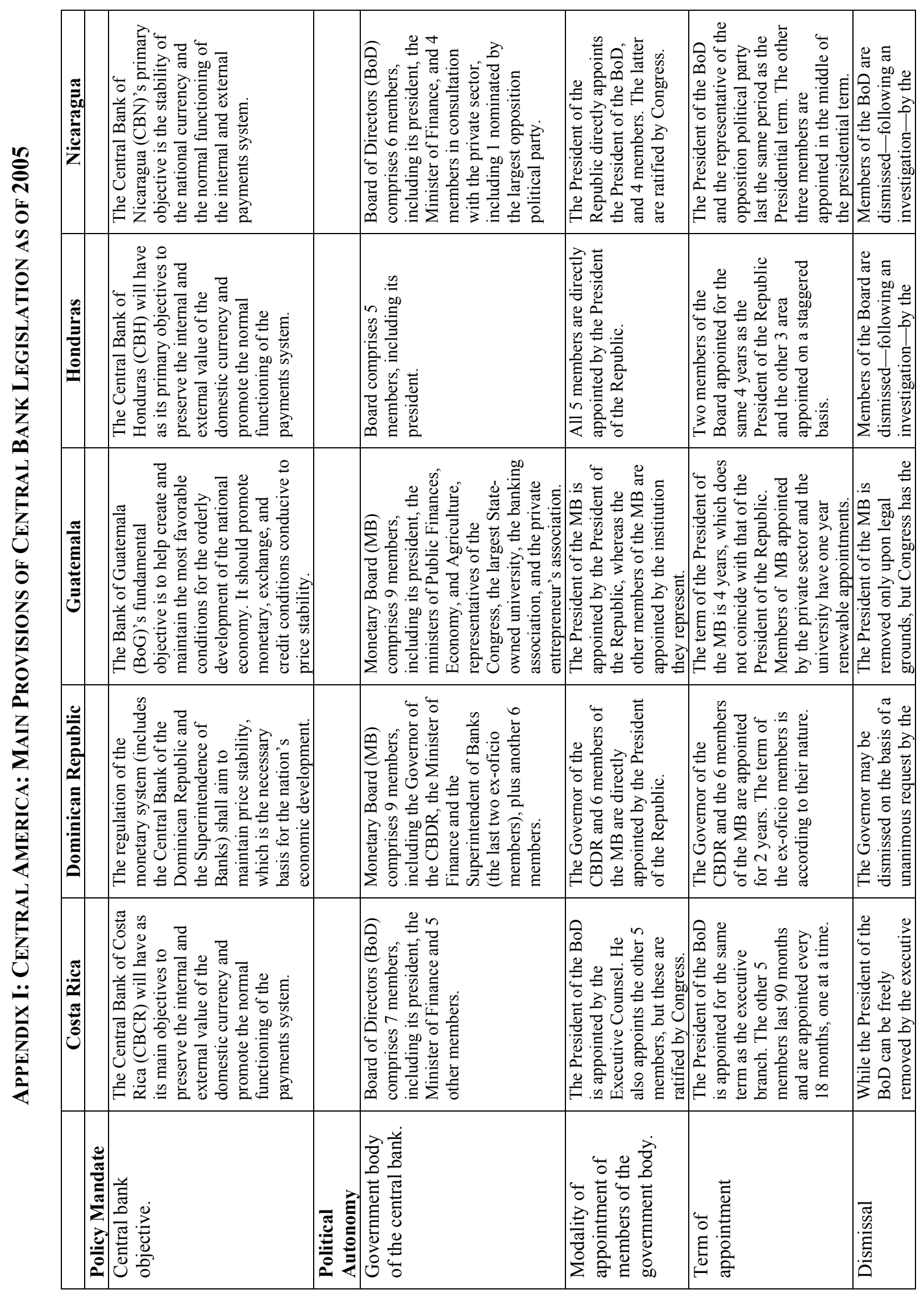




\begin{tabular}{|c|c|c|c|c|c|c|c|}
\hline 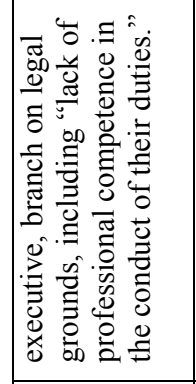 & & 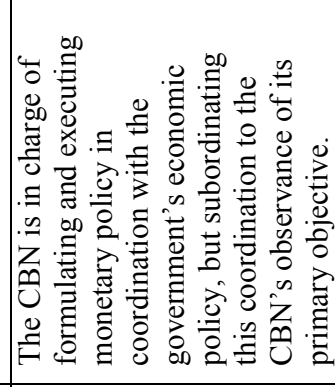 & 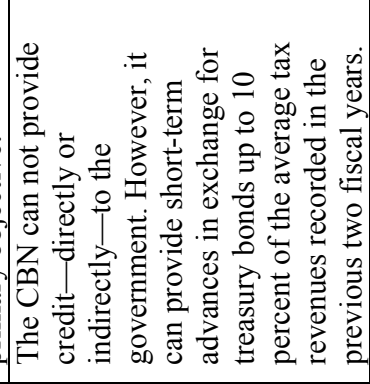 & 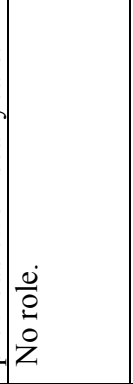 & 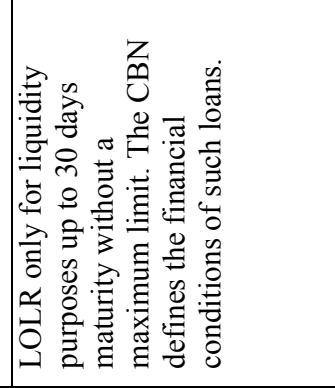 & & 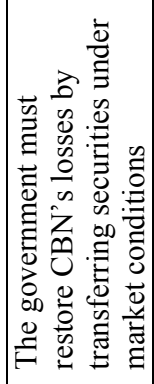 \\
\hline 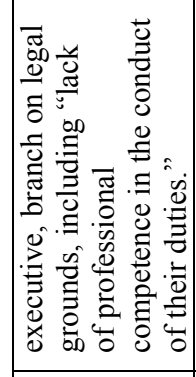 & & 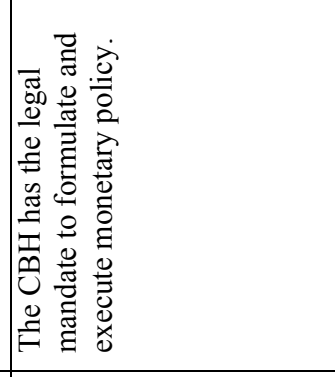 & 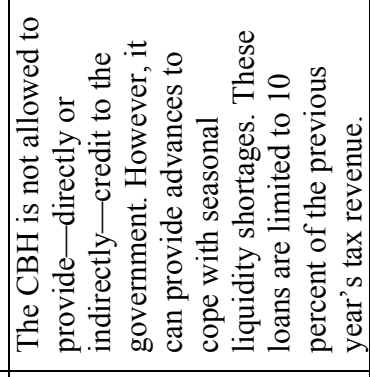 & 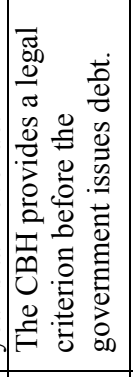 & 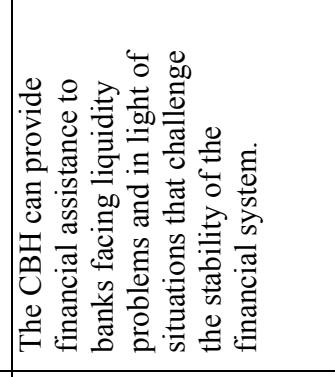 & & 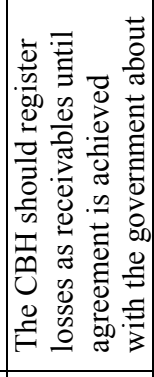 \\
\hline 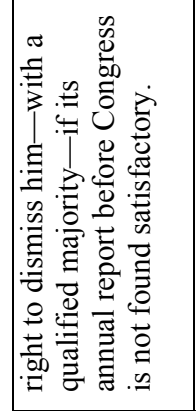 & & 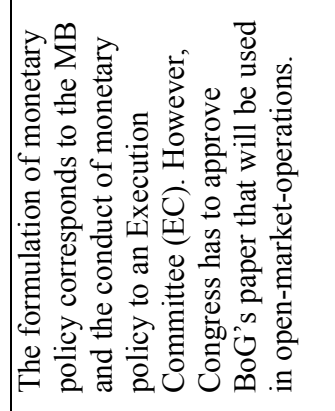 & 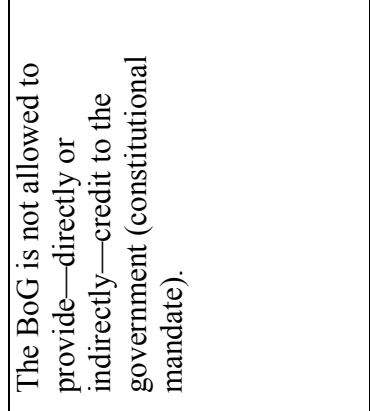 & 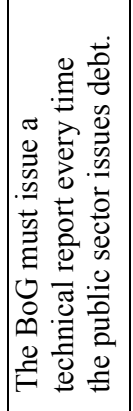 & 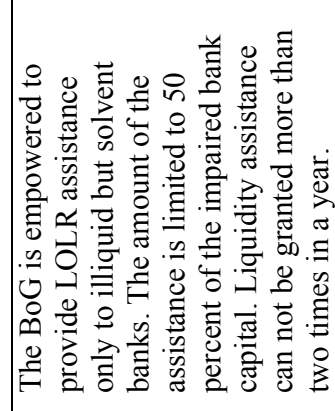 & & 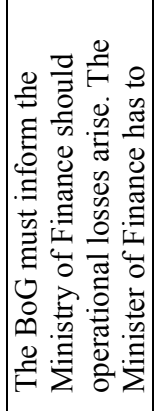 \\
\hline 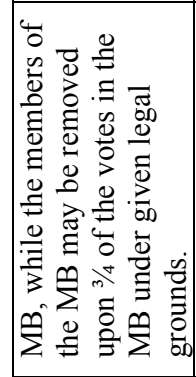 & & 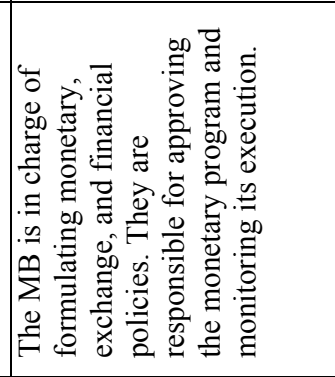 & 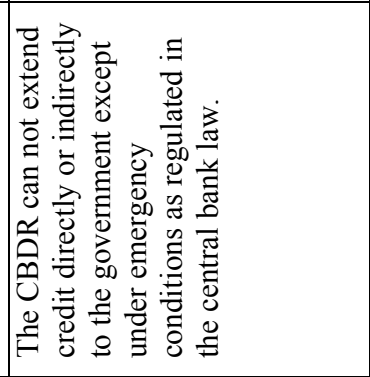 & & 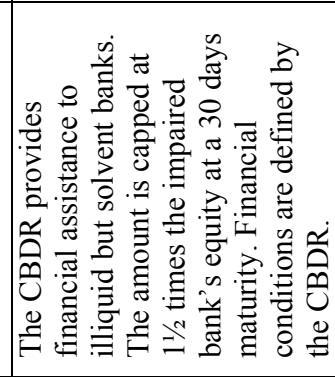 & & 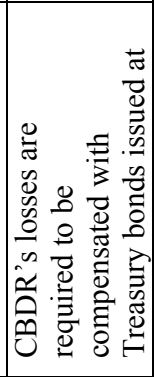 \\
\hline 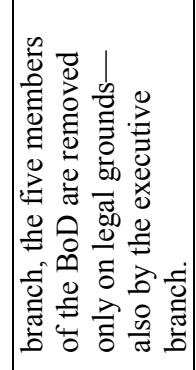 & & 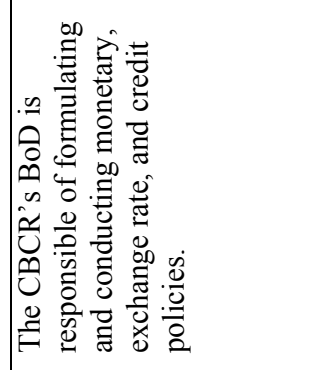 & 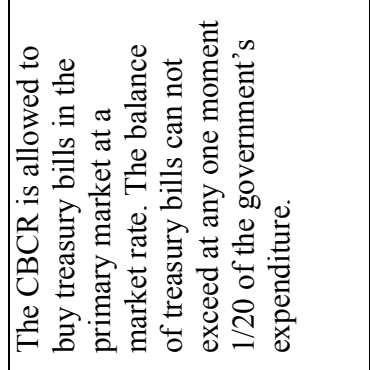 & 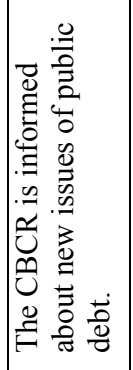 & 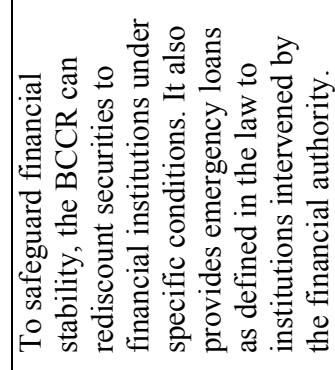 & & 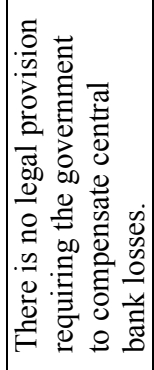 \\
\hline & 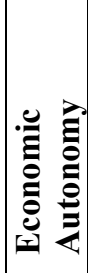 & 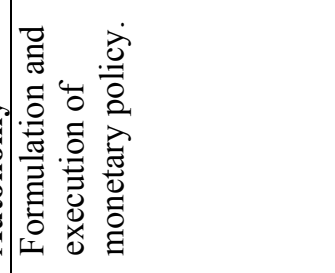 & 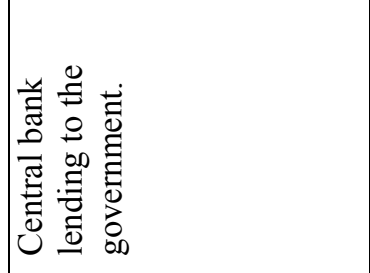 & 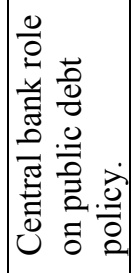 & 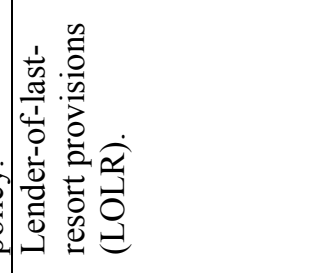 & 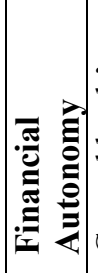 & 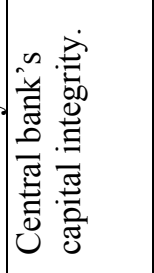 \\
\hline
\end{tabular}




\begin{tabular}{|c|c|c|c|c|c|c|}
\hline & 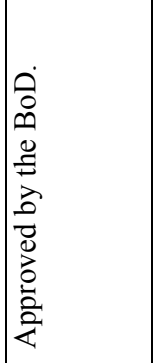 & & 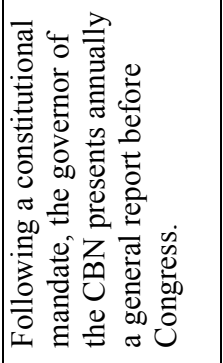 & 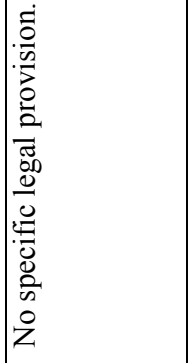 & 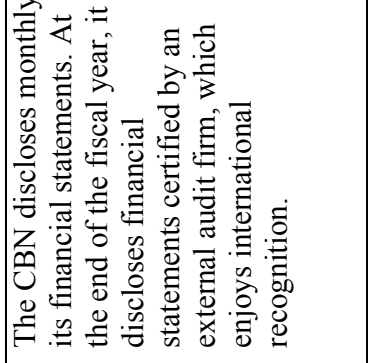 & 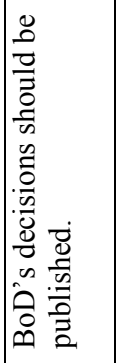 \\
\hline 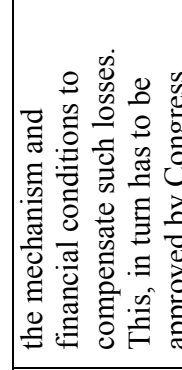 & 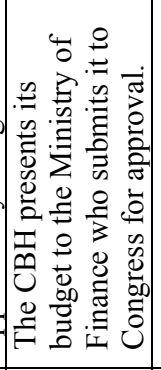 & & 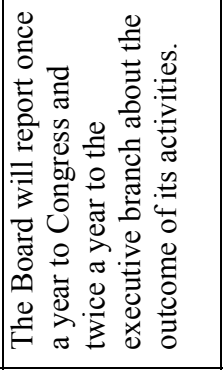 & 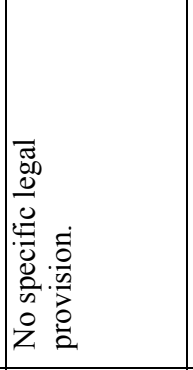 & 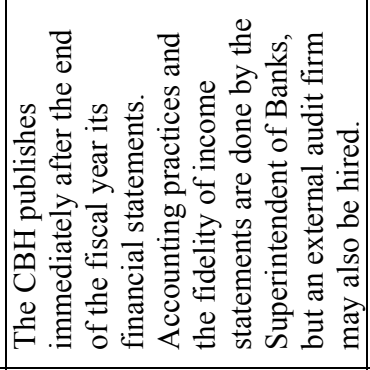 & 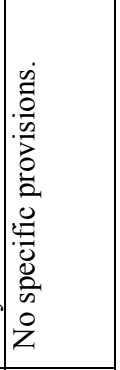 \\
\hline 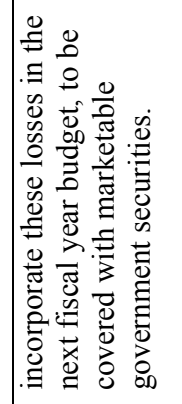 & 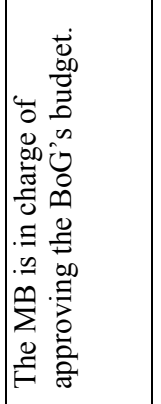 & & 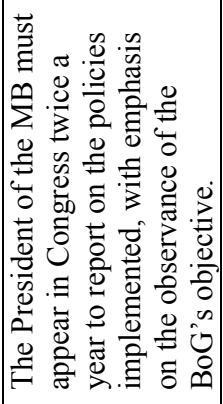 & 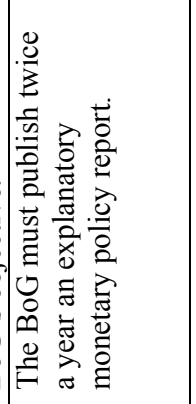 & 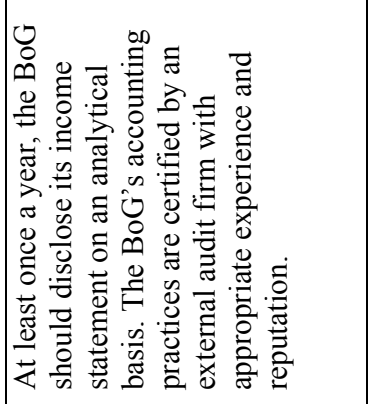 & 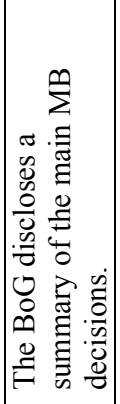 \\
\hline \multirow[t]{3}{*}{ 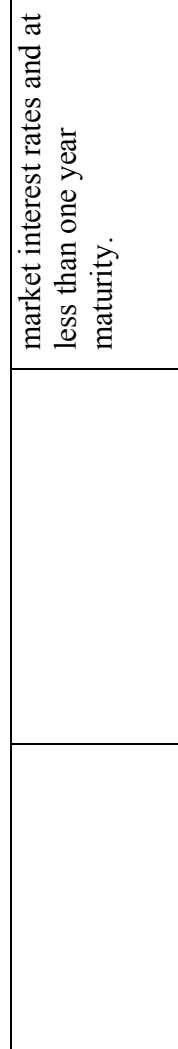 } & 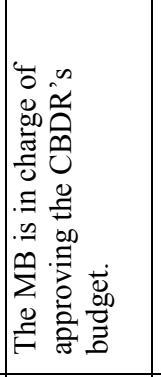 & & 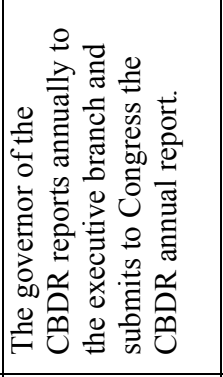 & 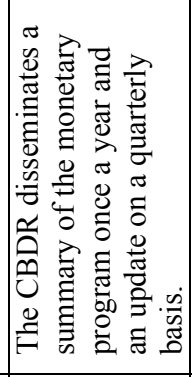 & 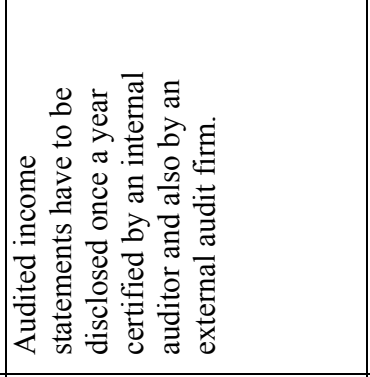 & 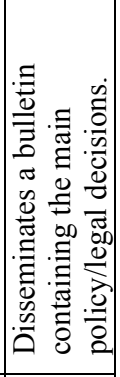 \\
\hline & 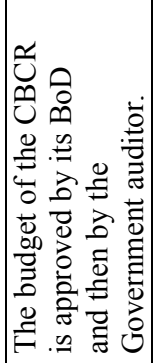 & & 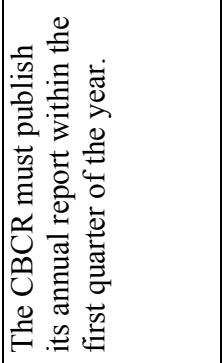 & 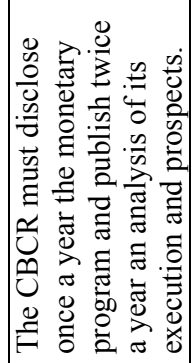 & 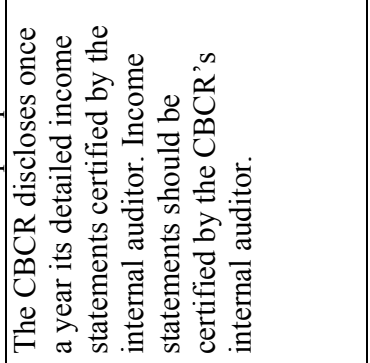 & 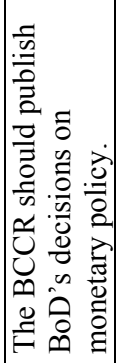 \\
\hline & 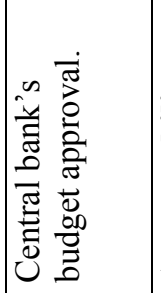 & 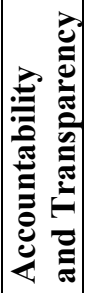 & 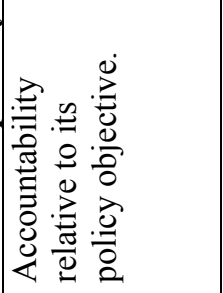 & 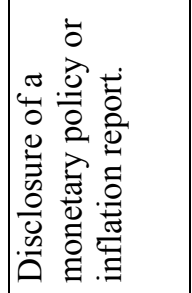 & 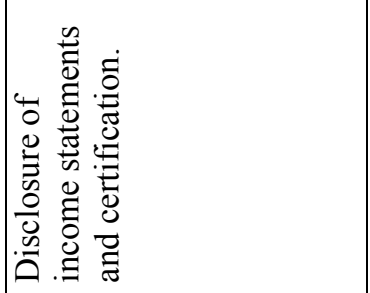 & 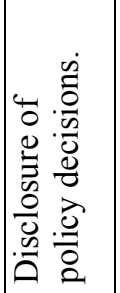 \\
\hline
\end{tabular}




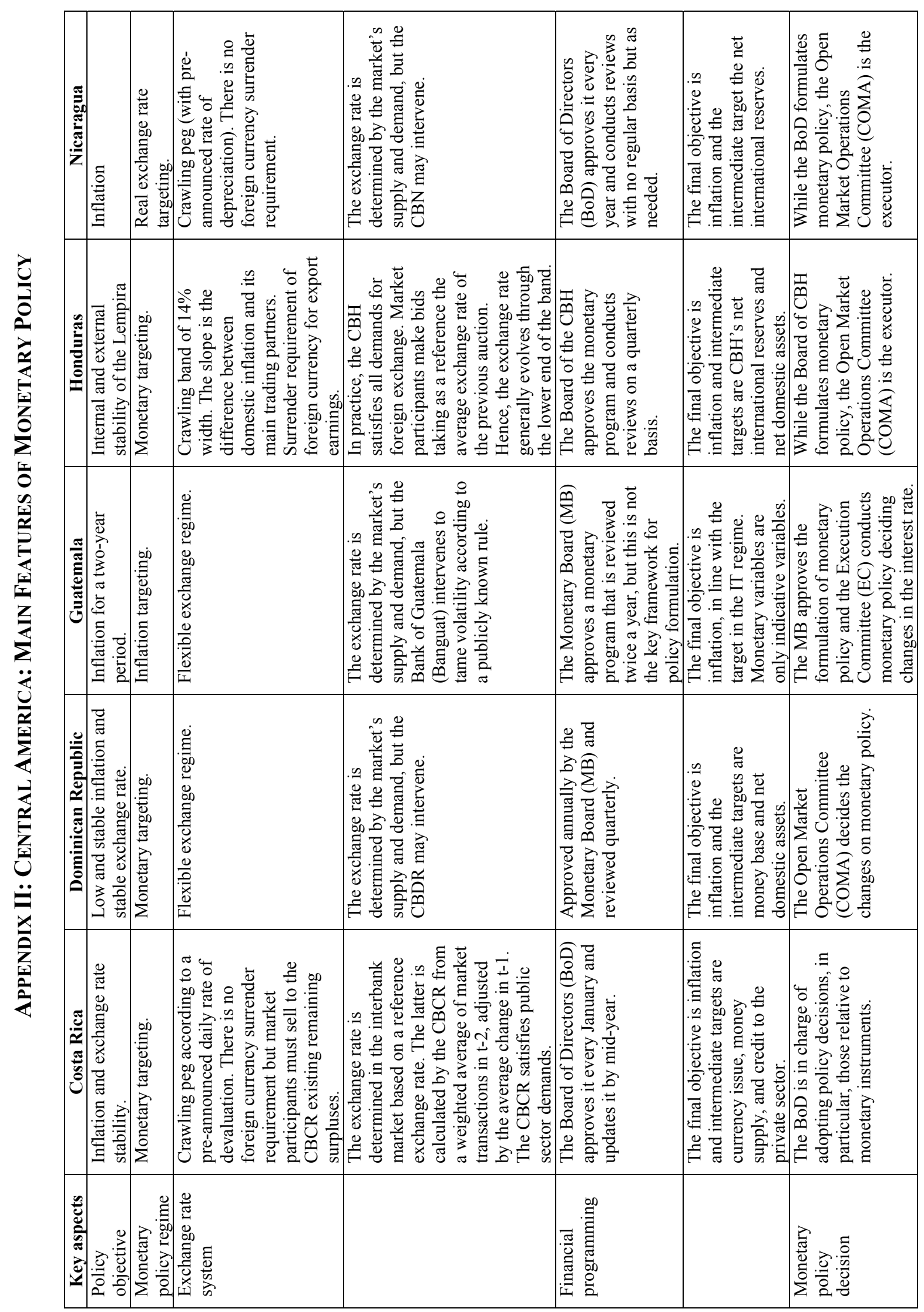




\begin{tabular}{|c|c|c|c|c|}
\hline 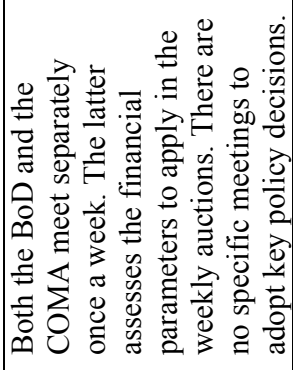 & 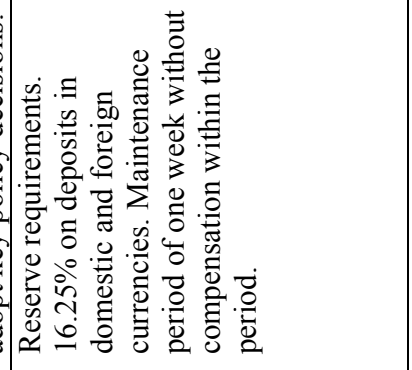 & 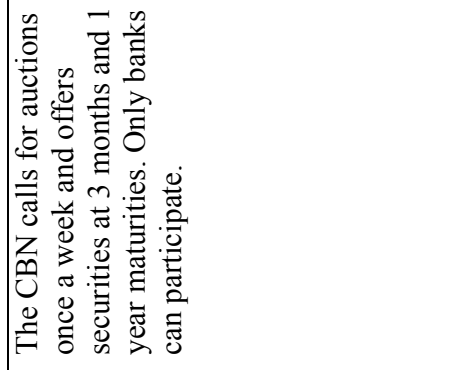 & 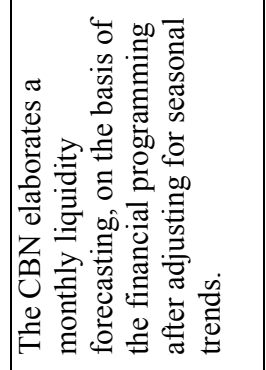 & 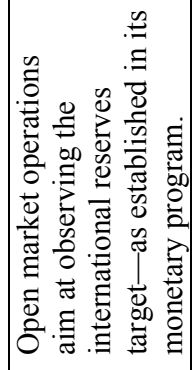 \\
\hline 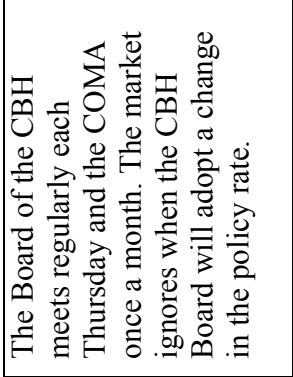 & 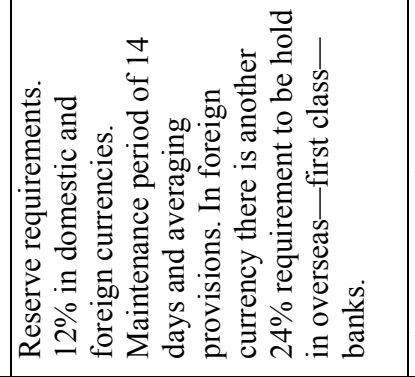 & 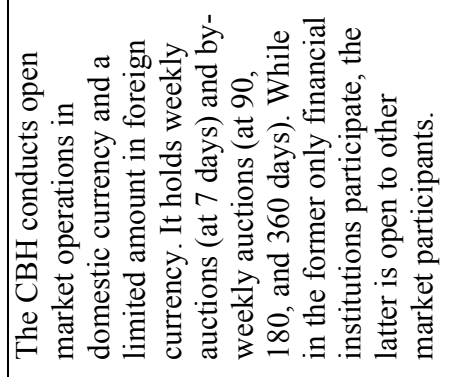 & 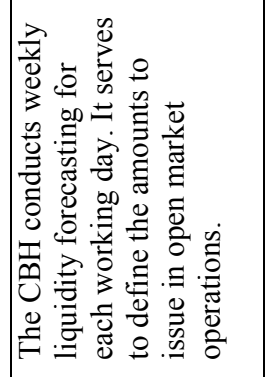 & 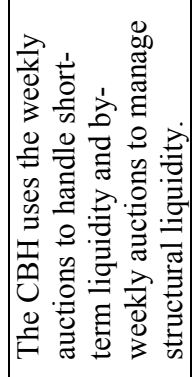 \\
\hline 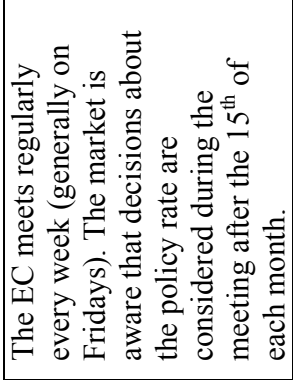 & 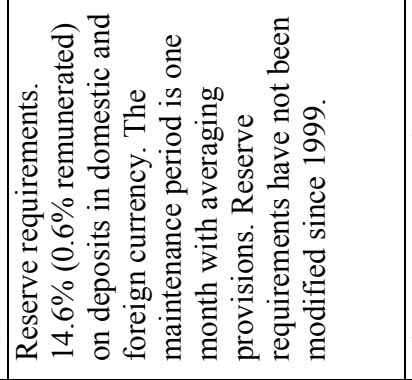 & 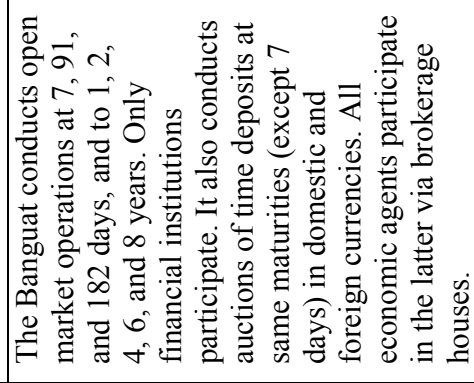 & 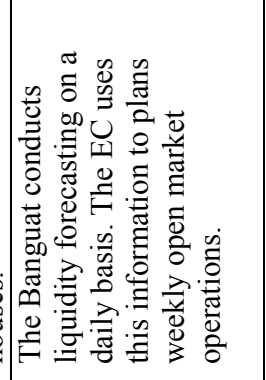 & 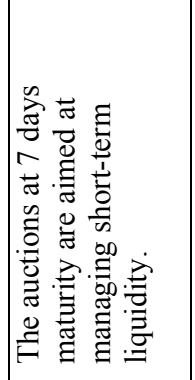 \\
\hline 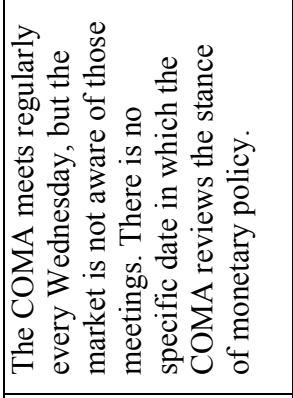 & 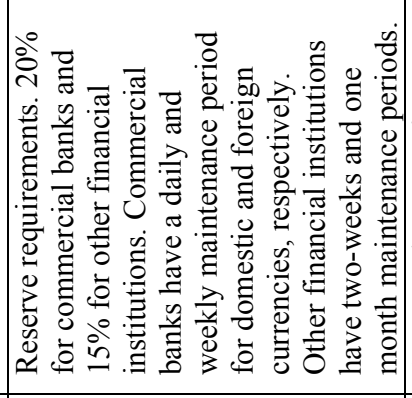 & 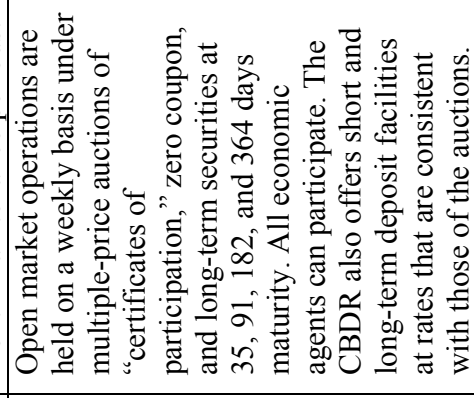 & 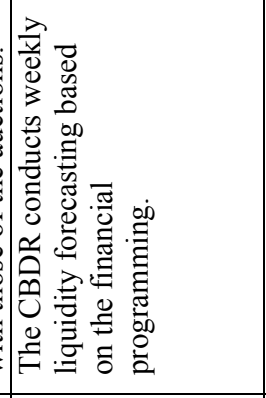 & 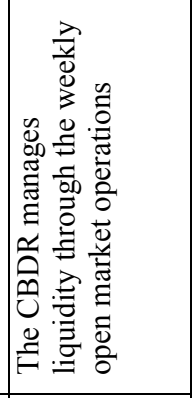 \\
\hline \multirow[t]{2}{*}{ 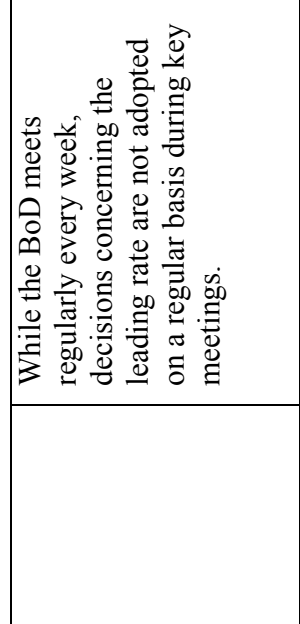 } & 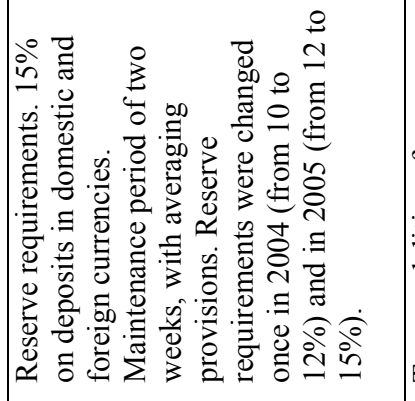 & 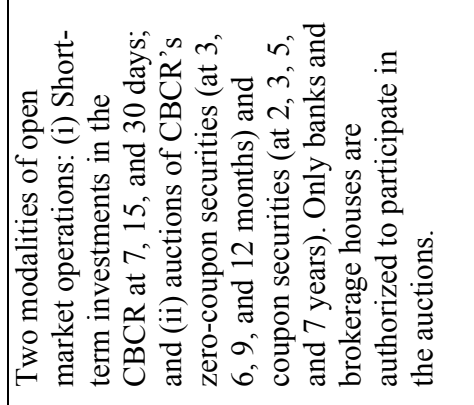 & 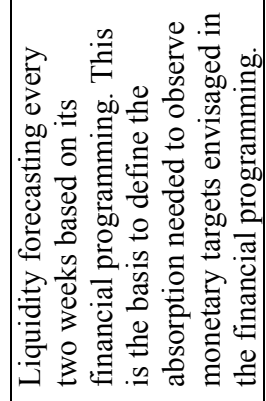 & 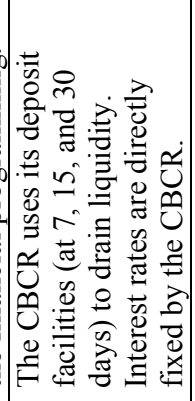 \\
\hline & 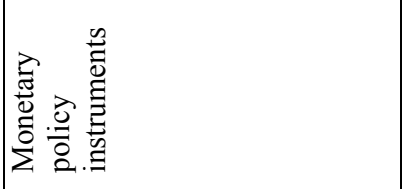 & & 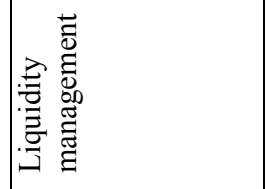 & \\
\hline
\end{tabular}




\begin{tabular}{|c|c|c|c|c|c|c|}
\hline 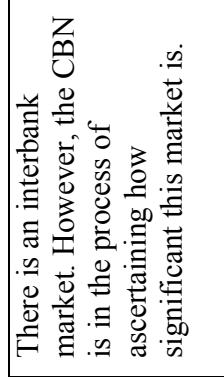 & 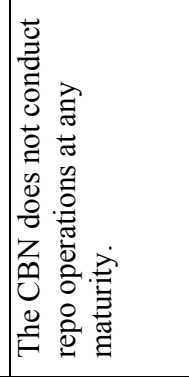 & 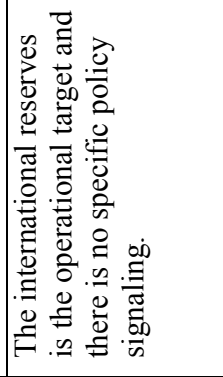 & 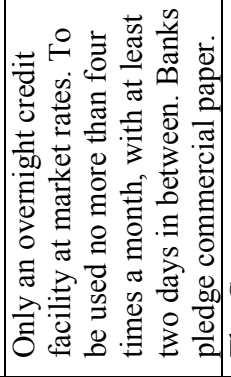 & 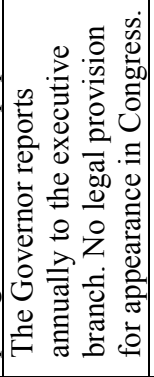 & 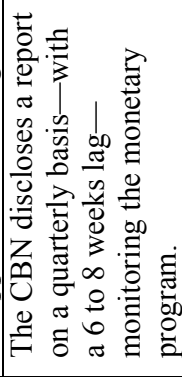 & 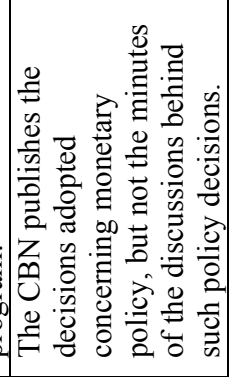 \\
\hline 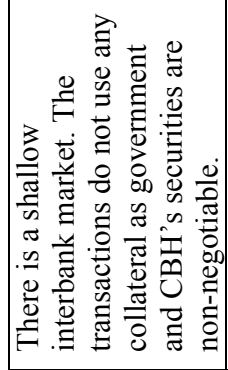 & 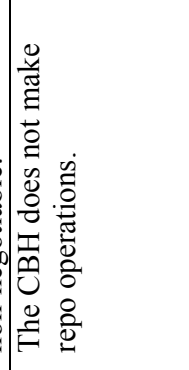 & 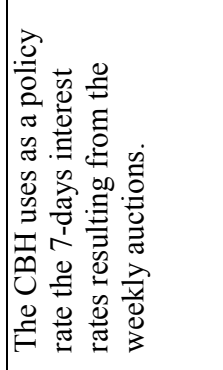 & 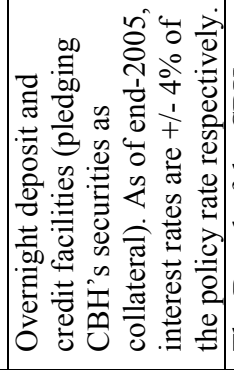 & 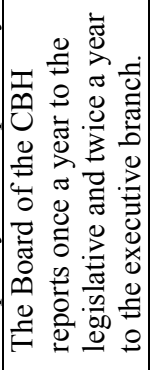 & 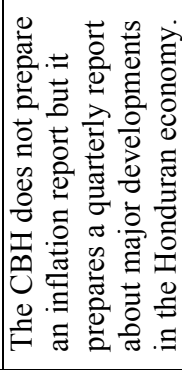 & 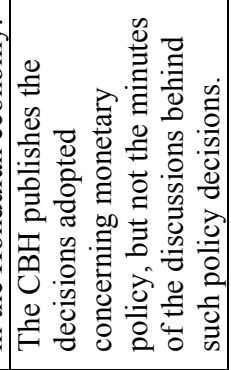 \\
\hline 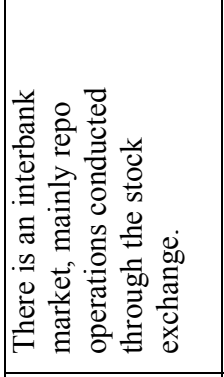 & 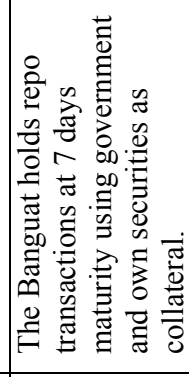 & 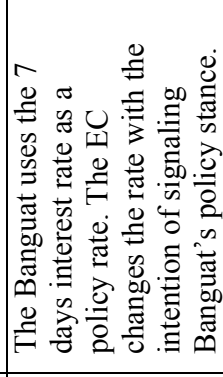 & 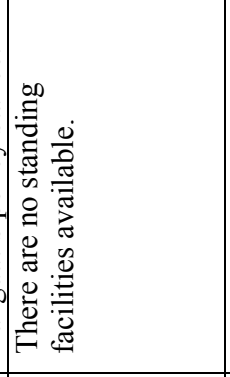 & 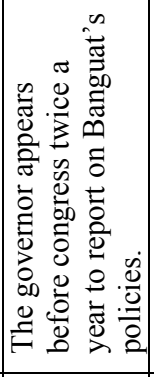 & 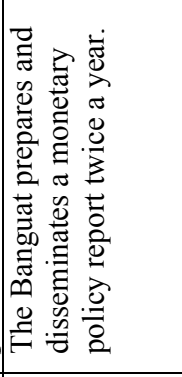 & 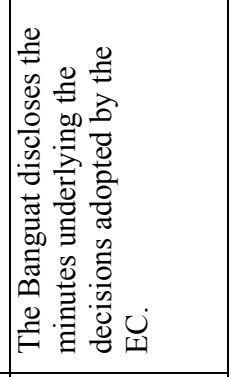 \\
\hline 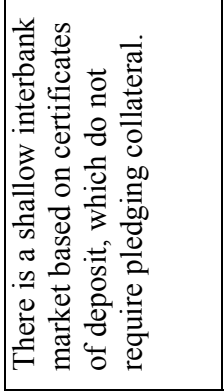 & 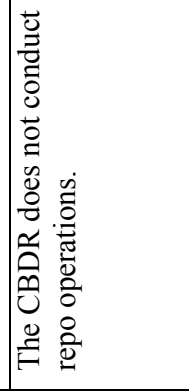 & 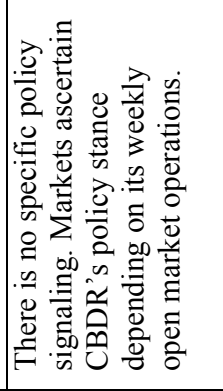 & 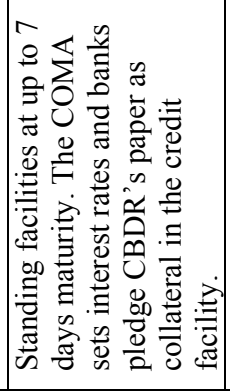 & 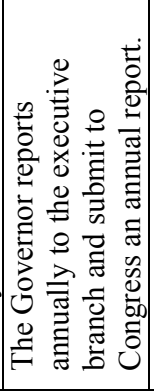 & 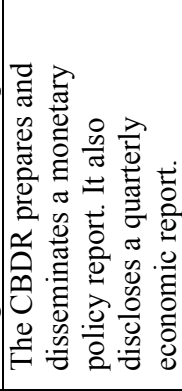 & 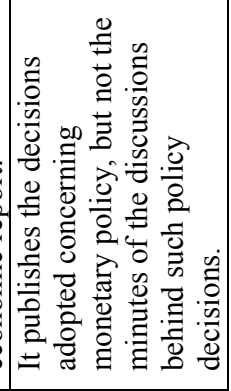 \\
\hline 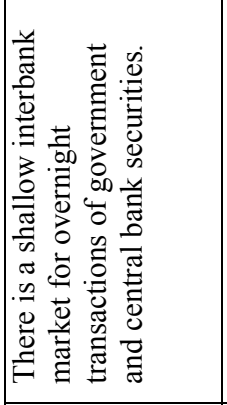 & 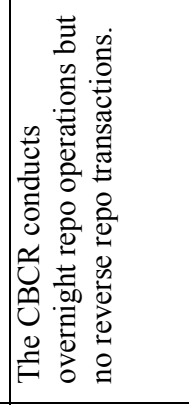 & 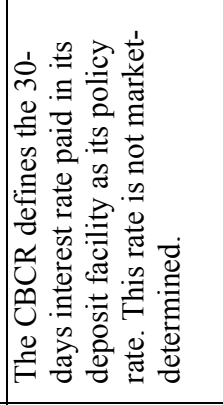 & 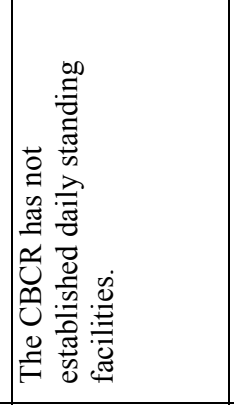 & 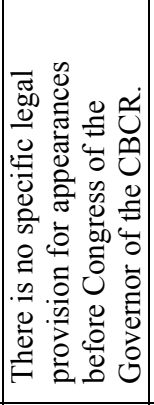 & 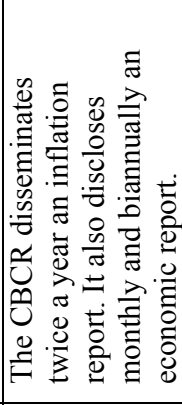 & 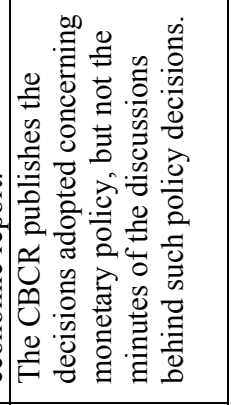 \\
\hline & & 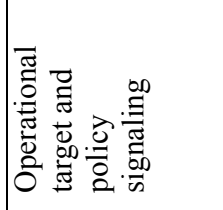 & 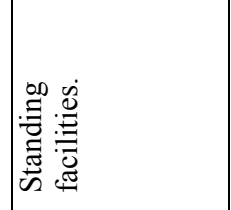 & 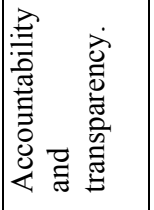 & & \\
\hline
\end{tabular}




\section{Appendix III: Policy Reaction Function}

The policy reaction function would work as follows: assume that within each operating period the central bank has a target for the interest rate, $i_{t}^{*}$, that is based on the state of the economy. Let it also be assumed that monetary authorities care about stabilizing inflation and output, so we allow for the possibility that the central bank adjusts its policy response to anticipated inflation and output. Specifically:

$$
i_{t}^{*}=\bar{i}+\beta\left(E\left[\pi_{t+n} \mid \Omega_{t}\right]-\pi^{*}\right)+\gamma\left(E\left[y_{t+m} \mid \Omega_{t}\right]-y^{*}\right),
$$

where $\bar{i}$ is the long-run equilibrium interest rate, $\pi_{t+n}$ is the rate of inflation between periods $t$ and $t+n, y_{t+m}$ is real output between periods $t$ and $t+m$, and $\pi^{*}$ and $y^{*}$ are the targets for inflation and output, respectively. In particular, $y^{*}$ is defined as the equilibrium level of output that would arise if wages and prices were perfectly flexible. Additionally, $E$ is the expectation operator and $\Omega_{t}$ is the information available to the policy maker. The expression could include additional independent terms such as the exchange rate and international reserves.

To capture concerns about potentially disruptive shifts in the interest rate, it is assumed that the interest rate is adjusted only partially to its target level:

$$
i_{t}=(1-\rho) i_{t}^{*}+\rho i_{t-1}+v_{t}
$$

where the parameter $\rho \in[0,1]$ captures the degree of interest rate smoothing. The exogenous random shock to the exchange rate, $v_{t}$, is assumed to be i.i.d. To define an estimable equation, let $\alpha=\bar{i}-\beta \pi^{*}$ and $x_{t}=y_{t}-y^{*}$, then equation (2) can be written as:

$$
i_{t}^{*}=\alpha+\beta E\left[\pi_{t+n} \mid \Omega_{t}\right]+\gamma E\left[x_{t+m} \mid \Omega_{t}\right]
$$

So, combining equation (3) with the partial adjustment mechanism (2) and eliminating the unobserved forecast variables yields:

$$
i_{t}=(1-\rho) \alpha+(1-\rho) \beta \pi_{t+n}+(1-\rho) \gamma x_{t+m}+\rho i_{t-1}+\varepsilon_{t}
$$

where the error term $\varepsilon_{t}$ is a linear combination of the forecast errors of inflation and output, and the exogenous disturbance $v_{t}$. 
Let $u_{t}$ be a vector of variables (set of instruments) within the policymaker's information set (i.e., $u_{t} \in \Omega_{t}$ ) that are orthogonal to $\varepsilon_{t}$. Possible elements of $u_{t}$ include any lagged variables that help forecast inflation and output, as well as any contemporaneous variables that are uncorrelated with the current exchange rate shock $v_{t}$. Thus, since $E\left[\varepsilon_{t} \mid u_{t}\right]=0$, the following equation can be estimated using the Generalized Method of Moments (GMM) with an optimal weighting matrix: $:^{28}$

$$
E\left[i_{t}-(1-\rho) \alpha-(1-\rho) \beta \pi_{t+n}-(1-\rho) \gamma x_{t+m}-\rho i_{t-1} \mid u_{t}\right]=0 .
$$

Equation (5) is estimated over the sample period from 1996 to 2005 with year-on-year CPI inflation, detrended IMAE (using the Hodrick-Prescott filter), and the nominal interest rate. Baseline elements of $u_{t}$ are lagged values of CPI inflation, output, and the interest rate. The forward-looking horizons are varied (values $n$ and $m$ in the case of inflation and output, respectively) to assess the policy horizon.

\footnotetext{
${ }^{28}$ The use of an optimal weighting matrix implies that GMM estimates are robust to heteroskedasticity and autocorrelation of unknown form. It is worth noting that the GMM technique requires no information about the exact distribution of the error term which, in general, is assumed to be drawn from a normal distribution.
} 


\section{REFERENCES}

Calvo, Guillermo and Carmen M. Reinhart, 2002, "Fear of floating," Quarterly Journal of Economics, CXVII (2), pp. 379-408.

Carstens, Agustín and Luis I. Jácome H., 2005, “The 1990s Institutional Reform of Monetary Policy in Latin America," Working Paper No. 343, (Central Bank of Chile).

Corbo, Vittorio, 2002, "Monetary policy in Latin America in the 1990s," in Norman Loayza and Klaus Schmidt-Hebbel (eds), Monetary Policy: Rules and Transmission Mechanisms, Central Bank of Chile, pp. 117-65.

Cukierman, Alex, 1992, Central Bank Strategy, Credibility, and Independence: Theory and Evidence (Cambridge, Massachusetts: The MIT Press).

Eichengreen, Barry, 2002, "Can emerging markets float? Should they Inflation Target?" Working Paper Series No. 36, Banco Central do Brasil, February.

Goldstein, Morris and Philip Turner, 2004, Controlling Currency Mismatches in Emerging Economies: an Alternative to the Original Sin Hypothesis, Institute for International Economics.

Jácome, Luis I. and Francisco Vázquez, 2005, “Any Link Between Legal Central Bank Independence and Inflation? Evidence from Latin America and the Caribbean" IMF Working Paper 05/75, (Washington: International Monetary Fund).

McCallum, Bennett, 1988, "Robustness properties of a rule for monetary policy," CarnegieRochester Conference Series on Public Society, 29, pp. 173-204.

Parrado, Eric, 2004, “Singapore's Unique Monetary Policy: How Does it Work?” IMF Working Paper 04/10, (Washington: International Monetary Fund).

Rennhack, Robert and Erik Offerdal, 2004, The Macroeconomy of Central America, International Monetary Fund, (Palgrave Macmillan).

Rodlauer, Markus and Alfred Schipke, 2005, "Central America: Global Integration and Regional Cooperation," Occasional Paper 243, (Washington: International Monetary Fund).

Taylor, John, 1993, "Discretion versus Policy Rules in Practice," Carnegie-Rochester Conference Series on Public Policy 39, pp. 195-214. 